\title{
Reducing C-Terminal-Truncated Alpha-Synuclein by Immunotherapy Attenuates Neurodegeneration and Propagation in Parkinson's Disease-Like Models
}

\author{
Dora Games, ${ }^{1}$ Elvira Valera, ${ }^{2}$ Brian Spencer, ${ }^{2}$ Edward Rockenstein, ${ }^{2}$ Michael Mante, ${ }^{2}$ Anthony Adame, ${ }^{2}$ \\ Christina Patrick, ${ }^{2}$ Kiren Ubhi, ${ }^{2}$ Silke Nuber, ${ }^{2}$ Patricia Sacayon, ${ }^{1}$ Wagner Zago, ${ }^{1}$ Peter Seubert, ${ }^{1}$ Robin Barbour, ${ }^{1}$ \\ Dale Schenk, ${ }^{1}$ and Eliezer Masliah ${ }^{2,3}$ \\ ${ }^{1}$ Prothena Biosciences, South San Francisco, California 94080, and ${ }^{2}$ Department of Neurosciences and ${ }^{3}$ Department of Pathology, University of California, \\ San Diego, La Jolla, California 92093
}

\begin{abstract}
Parkinson's disease (PD) and dementia with Lewy bodies (DLB) are common neurodegenerative disorders of the aging population, characterized by progressive and abnormal accumulation of $\alpha$-synuclein ( $\alpha$-syn). Recent studies have shown that C-terminus (CT) truncation and propagation of $\alpha$-syn play a role in the pathogenesis of PD/DLB. Therefore, we explored the effect of passive immunization against the CT of $\alpha$-syn in the mThyl- $\alpha$-syn transgenic (tg) mouse model, which resembles the striato-nigral and motor deficits of PD. Mice were immunized with the new monoclonal antibodies 1H7, 5C1, or 5D12, all directed against the CT of $\alpha$-syn. CT $\alpha$-syn antibodies attenuated synaptic and axonal pathology, reduced the accumulation of CT-truncated $\alpha$-syn (CT- $\alpha$-syn) in axons, rescued the loss of tyrosine hydroxylase fibers in striatum, and improved motor and memory deficits. Among them, $1 \mathrm{H} 7$ and $5 \mathrm{C} 1$ were most effective at decreasing levels of CT- $\alpha$-syn and higher-molecular-weight aggregates. Furthermore, in vitro studies showed that preincubation of recombinant $\alpha$-syn with $1 \mathrm{H} 7$ and $5 \mathrm{C} 1$ prevented CT cleavage of $\alpha$-syn. In a cell-based system, CT antibodies reduced cell-to-cell propagation of full-length $\alpha$-syn, but not of the CT- $\alpha$-syn that lacked the 118-126 aa recognition site needed for antibody binding. Furthermore, the results obtained after lentiviral expression of $\alpha$-syn suggest that antibodies might be blocking the extracellular truncation of $\alpha$-syn by calpain-1. Together, these results demonstrate that antibodies against the CT of $\alpha$-syn reduce levels of CT-truncated fragments of the protein and its propagation, thus ameliorating PD-like pathology and improving behavioral and motor functions in a mouse model of this disease.
\end{abstract}

Key words: $\alpha$-synuclein; $\alpha$-synuclein propagation; $\alpha$-synuclein truncation; calpain; immunotherapy; Parkinson's disease

\section{Introduction}

Neurodegenerative conditions with neuronal accumulation of $\alpha$-synuclein ( $\alpha$-syn) are common causes of dementia and movement disorders in the aging population (Savica et al., 2013). This group of disorders includes idiopathic Parkinson's disease (PD), PD dementia (PDD), and dementia with Lewy bodies (DLB), jointly known as Lewy body diseases (LBDs; McKeith, 2000). $\alpha$-syn is a 140 aa protein (Uéda et al., 1993; George et al., 1995; Weinreb et al., 1996) found at the presynaptic terminals (Iwai et al., 1995b) that may be involved in synaptic plasticity (Murphy et

Received Dec. 19, 2013; revised June 7, 2014; accepted June 10, 2014

Author contributions: D.G., E.V., B.S., E.R., K.U., S.N., P. Seubert, R.B., D.S., and E.M. designed research; E.V., B.S., E.R., M.M., A.A., C.P., P. Sacayon, R.B., and E.M. performed research; E.M. contributed unpublished reagents/analytic tools; D.G., E.V., B.S., E.R., K.U., S.N., P. Sacayon, W.Z.,P. Seubert, R.B., and E.M. analyzed data; D.G., E.V., S.N., W.Z., P. Seubert, D.S., and E.M. wrote the paper.

This work was supported by the National Institutes of Health (Grants AG11385, AG18840, AG022074, and NS044233) and Prothena Biosciences.

D.G., P.S., W.Z., P.S., R.B., and D.S. are employees of Prothena, the company that develops the antibodies described in the manuscript. The remaining authors declare no competing financial interests.

Correspondence should be addressed to Eliezer Masliah, M.D. University of California-San Diego, 9500 Gilman Drive, La Jolla, CA 92093-0624. E-mail: emasliah@ucsd.edu.

DOI:10.1523/JNEUROSCI.5314-13.2014

Copyright $\odot 2014$ the authors $\quad 0270-6474 / 14 / 349441-14 \$ 15.00 / 0$ al., 2000). Abnormal $\alpha$-syn accumulation in synaptic terminals (Kramer and Schulz-Schaeffer, 2007; Roy et al., 2007; Bellucci et al., 2012) and axons (Games et al., 2013) plays an important role in LBD (Iwatsubo et al., 1996; Trojanowski and Lee, 1998; Hashimoto and Masliah, 1999; Lansbury, 1999), and an increasing body of evidence supports the notion that $\alpha$-syn oligomerization (Conway et al., 1998; Tsigelny et al., 2008; Winner et al., 2011; Lashuel et al., 2013) and fibril growth (Oueslati et al., 2010; Taschenberger et al., 2012) have central roles in the pathogenesis of PD and other $\alpha$-synucleinopathies (Galvin et al., 2001). Moreover, $\alpha$-syn oligomers can be released by neurons and lead to neurodegeneration and inflammation by propagating to other neurons (Desplats et al., 2009; Brundin et al., 2010; Lee et al., 2012) and glial cells (Lee et al., 2010). Recent studies have also shown that C-terminus (CT) truncation of $\alpha$-syn results in the formation of toxic fragments and facilitates $\alpha$-syn oligomerization and propagation (Mishizen-Eberz et al., 2003; Li et al., 2005; Dufty et al., 2007; Michell et al., 2007).

Currently, there are no disease-modifying therapies available for $\alpha$-synucleinopathies, but potential strategies might include reducing $\alpha$-syn expression or aggregation, or increasing its clearance via chaperones, the proteasome, or autophagy (Stefanis, 
2012; Lashuel et al., 2013). We have shown previously that active immunization with $\alpha$-syn protects against neurodegeneration and reduces $\alpha$-syn accumulation by promoting its degradation via lysosomal pathways (Masliah et al., 2005). In addition, passive immunization with antibodies against $\alpha$-syn reduces memory and neurodegenerative deficits by promoting clearance of $\alpha$-syn via autophagy (Masliah et al., 2011) or microglia (Bae et al., 2012). Immunization might also be of therapeutic value by reducing $\alpha$-syn propagation (Bae et al., 2012; Valera and Masliah, 2013 ) or CT truncation of $\alpha$-syn. Therefore, we investigated the utility of passive immunization with novel antibodies that target the CT region of $\alpha$-syn in the mThyl- $\alpha$-syn transgenic ( $\mathrm{tg}$ ) mouse model, which shows accumulation of CT-cleaved $\alpha$-syn (Games et al., 2013) and degeneration of the striato-nigral system (Chesselet et al., 2012) accompanied by motor deficits (Fleming et al., 2004). Immunotherapy reduced the accumulation of CTtruncated $\alpha$-syn and improved axonal and motor deficits by protecting $\alpha$-syn from CT cleavage. Furthermore, the antibodies that reduced CT truncation also reduced cell-to-cell propagation of $\alpha$-syn. Immunization with antibodies targeting the CT truncation site of $\alpha$-syn might have therapeutic potential, not only as $\alpha$-syn-reducing agents, but also as inhibitors of its pathological propagation.

\section{Materials and Methods}

Transgenic mouse model and passive immunization. Mice overexpressing human $\alpha$-syn under the mThyl promoter (mThyl- $\alpha$-syn, line 61) were used (Rockenstein et al., 2002). This model was selected because mice develop behavioral motor deficits (Fleming et al., 2004), axonal pathology, and accumulation of CT-cleaved $\alpha$-syn and aggregates in cortical and subcortical regions (Games et al., 2013), thus mimicking PD (Masliah et al., 2001; Rockenstein et al., 2007). A total of $70 \alpha$-syn tg and 14 non-tg mice, all of them 6 months old and female, were included in this randomized, double-blind study. The $\alpha$-syn tg mice were immunized weekly, for 6 months, with an injection $(10 \mathrm{mg} / \mathrm{kg}$, i.p.) of the novel IgG1 $\alpha$-syn antibodies $1 \mathrm{H} 7$ (syn aa 91-99), 5C1 (syn aa 118-126), 5D12 (syn aa 118-126), or control IgG1 (27-1) ( $n=14$ per group). Mice were also immunized with the antibody 9E4 (syn aa 118-126) as a reference control because we have shown previously that this antibody was effective for passive immunization in a DLB mouse model (Masliah et al., 2011). 1 H7 was generated using recombinant $\alpha$-syn. 5D12 was generated against CGG-VDPDNEAYE (syn aa 118-126), in which the CGGs are artificial and used to couple via maleamide linkage to sheep anti-mouse IgG. 5C1 was generated against VDPDNEAYE-GGC using the same linker to couple it to sheep anti-mouse IgG. Non-tg mice were treated with control IgG1 only $(27-1 ; n=14)$. Blood samples were taken once a month and antibody titers were monitored by ELISA. Affinity of the antibodies to $\alpha$-syn was measured by surface plasmon resonance (Biacore). The purified antibodies were covalently immobilized to a CM5 sensor chip via amine group using the amine coupling kit such that the maximum binding of $\alpha$-syn would not exceed 50-80 resonance units. Various concentrations of $\alpha$-syn were flowed over the sensor until the higher concentrations resulted in equilibrium binding and were then allowed to dissociate until at least $10 \%$ of total bound $\alpha$-syn had dissociated. Data were blank-substracted and then analyzed using a global 1:1 fit.

Mice were tested behaviorally at the end of the immunization protocol. Brains and peripheral tissues were removed and brains were divided sagitally. The right hemibrain was postfixed in phosphate-buffered $4 \%$ paraformaldehyde, $\mathrm{pH} \mathrm{7.4,} \mathrm{at} 4^{\circ} \mathrm{C}$ for $48 \mathrm{~h}$ for neuropathological analysis. The left hemibrain was snap-frozen and stored at $-70^{\circ} \mathrm{C}$ for subsequent RNA and protein analysis. All experiments described were approved by the animal subjects committee at the University of California San Diego (UCSD) and were performed according to the National Institutes of Health's Guide for the Care and Use of Laboratory Animals.

Behavioral testing. mThy1- $\alpha$-syn tg mice have been shown to accumulate $\alpha$-syn in the striato-nigral system (Games et al., 2013) and to display dopaminergic loss (Chesselet et al., 2012) and motor deficits in the horizontal beam test (Fleming et al., 2004). The round beam test allows for the assessment of gait and balance impairments through distance traveled in an allotted amount of time over a round beam placed horizontally. As described previously (Ubhi et al., 2010), 3 consecutive trials, 1 min each, were run in $1 \mathrm{~d}$. The total forward distance traveled and the numbers of foot slippages were recorded. Speed on the beam was calculated as distance traveled/time and errors on the beam were calculated as foot slips/distance traveled.

In patients with $\mathrm{DLB} / \mathrm{PD}, \mathrm{CT}$-truncated and oligomeric $\alpha$-syn not only accumulate in subcortical regions, but also in the limbic system, resulting in cognitive deficits in these patients (Dickson, 2001). In the mThyl- $\alpha$-syn tg mice, CT-truncated and oligomeric $\alpha$-syn accumulates in synapses and axons in the temporal cortex and hippocampus (Games et al., 2013). To evaluate spatial learning and memory, mice were tested in the water maze (Masliah et al., 2011). Briefly, a pool (diameter $180 \mathrm{~cm}$ ) was filled with opaque water $\left(24^{\circ} \mathrm{C}\right)$ and mice were first trained to locate a visible platform (days $1-3$ ) and then a submerged hidden platform (days $4-7$ ) in 3 daily trials that were $2-3$ min apart. Mice that failed to find the hidden platform within $90 \mathrm{~s}$ were placed on it for $30 \mathrm{~s}$. The same platform location was used for all sessions and all mice. The starting point at which each mouse was placed into the water was changed randomly between two alternative entry points located at a similar distance from the platform. In addition, on the final day of testing, the platform was removed and the time spent by mice in the correct quadrant was measured (probe test). Time to reach the platform (escape latency) was recorded with an ANY-Maze video tracking system (San Diego Instruments) set to analyze two samples per second.

ELISA analysis of brain and plasma antibody concentrations. Antibody levels in the brain and plasma of immunized mice were determined as described previously (Masliah et al., 2005). Briefly, 96 well microtiter plates coated with $0.4 \mu \mathrm{g}$ per well of purified full-length $\alpha$-syn were used. Samples were incubated overnight, followed by goat anti-mouse IgG alkaline phosphatase-conjugated antibody (1:7500; Promega). The plate was read at wavelengths of 450 and $550 \mathrm{~nm}$. Results were plotted on a semilogarithmic graph with relative fluorescence units versus serum dilution. Antibody titer was defined as the dilution at which there was a $50 \%$ reduction from the maximal antibody signal.

Immunoblot analysis. As described previously, brains were homogenized and divided into cytosolic and particulate (membrane) fractions (Spencer et al., 2009; Crews et al., 2010). For immunoblot analysis, $20 \mu \mathrm{g}$ of total protein per lane was loaded into $4-12 \%$ Bis-Tris SDS-PAGE gels and blotted onto PVDF membranes. To determine the effects of the immunotherapy in $\alpha$-syn levels, blotted samples from treated $\alpha$-syn tg mice were probed with antibodies against CT- $\alpha$-syn (SYN105; Games et al., 2013), full-length (FL)- $\alpha$-syn (rabbit polyclonal 1:1000; Millipore), $\alpha$-syn (monoclonal 1:1000; BD Biosciences; Masliah et al., 2011), synaptophysin (SY38, 1:1000; Millipore), and PSD-95 (K28/43, 1:1000; NeuroMab). Incubation with primary antibodies was followed by species-appropriate incubation with secondary antibodies tagged with horseradish peroxidase (1:5000; Santa Cruz Biotechnology), visualization with enhanced chemiluminescence and analysis with a Versadoc XL imaging apparatus (Bio-Rad). Analysis of $\beta$-actin (Sigma) levels was used as a loading control.

Calpain-1-mediated degradation assay of $\alpha$-syn and antibody testing. 1 $\mu \mathrm{g}$ of recombinant FL $\alpha$-syn was digested with $0.2 \mathrm{U}$ of calpain-1 in buffer ( $40 \mathrm{~mm} \mathrm{HEPES;} 1 \mathrm{~mm} \mathrm{CaCl}_{2}$ ) at $37^{\circ} \mathrm{C}$ for 0,10 , and $40 \mathrm{~min}$ in the absence or presence of $27-1,9 \mathrm{E} 4,1 \mathrm{H} 7,5 \mathrm{C} 1$, or $5 \mathrm{D} 12(1 \mathrm{mg} / \mathrm{ml})$ and then incubated overnight at $4^{\circ} \mathrm{C}$. Control experiments included incubation with the calpain inhibitor Calpeptin at $40 \mu \mathrm{M}$. A total of $5 \mu \mathrm{l}$ of loading dye was then added to each sample, followed by heat for $10 \mathrm{~min}$ at $70^{\circ} \mathrm{C}$, and $15 \mu \mathrm{l}$ were loaded onto SDS-PAGE gels and analyzed by immunoblot. Blots were probed with antibodies against FL- $\alpha$-syn and CT- $\alpha$-syn, followed by incubation with species-appropriate secondary antibodies tagged with horseradish peroxidase (1:5000; Santa Cruz Biotechnology), visualization with enhanced chemiluminescence, and analysis with a Versadoc XL imaging apparatus (Bio-Rad).

Immunohistochemical and neuropathological analysis. Analysis of $\alpha$-syn accumulation was performed in serially sectioned, free-floating 

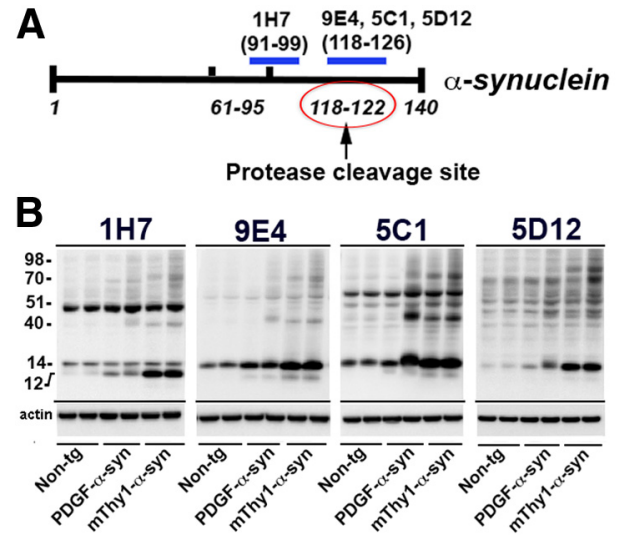

C

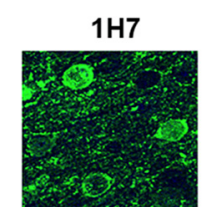

$5 \mathrm{C} 1$

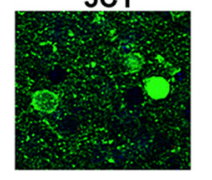

Figure 1. New antibodies directed against the $\mathrm{CT}$ of $\alpha$-syn recognized $\alpha$-syn by immunoblot and immunohistochemistry in $\alpha$-syn tg mice. $A$, Schematic representation of the $\alpha$-syn molecule and binding sites of (T $\alpha$-syn antibodies 1H7 (aa 91-99), 9E4 (aa 118-126), 5C1 (aa 118-126), and 5D12 (aa $118-126$ ). The protease cleavage site (118-122) is also depicted. B, Immunoblot analysis of non-tg, PDGF- $\alpha$-syn tg, and mThy1- $\alpha$-syn tg brain homogenates probed with $1 \mathrm{H} 7,9 \mathrm{E} 4,5 \mathrm{C} 1$, or $5 \mathrm{D} 12$ antibodies. The $14 \mathrm{kDa}$ band is monomeric $\alpha$-syn and the $12 \mathrm{kDa}$ band is $\mathrm{CT}-\alpha$-syn. Higher-molecular-weight bands correspond to different $\alpha$-syn oligomers. Actin was used as a loading control. C, mThy1- $\alpha$-syn tg mouse brain sections were immunostained with the CT $\alpha$-syn antibodies 1H7, 9E4, 5C1, or 5D12. Antibody binding was detected using a FITC-tagged secondary antibody. Scale bar, $10 \mu \mathrm{m}$.

$1 \mathrm{H} 7(\mu \mathrm{g} / \mathrm{ml})$

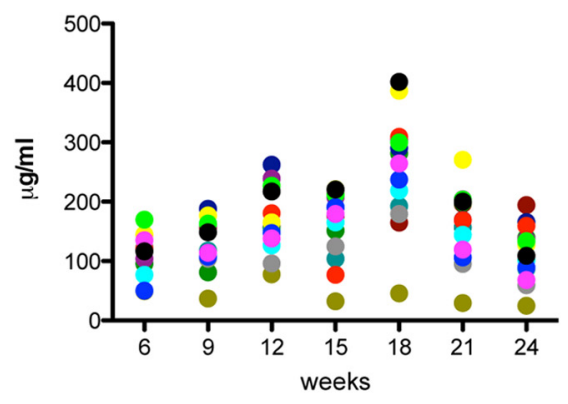

$5 \mathrm{D} 12(\mu \mathrm{g} / \mathrm{ml})$

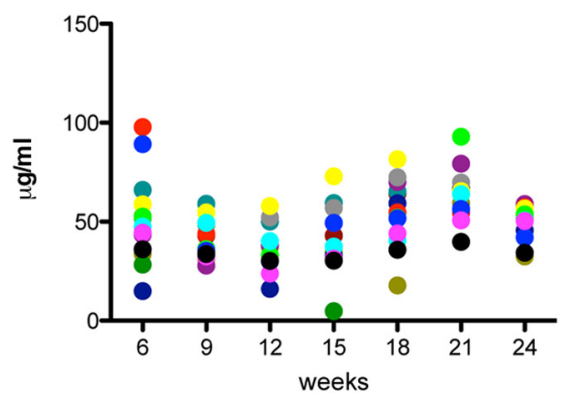

9E4 ( $\mu \mathrm{g} / \mathrm{ml})$

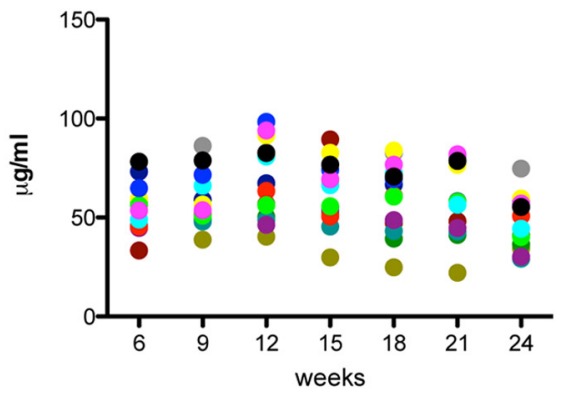

$5 \mathrm{C} 1(\mu \mathrm{g} / \mathrm{ml})$

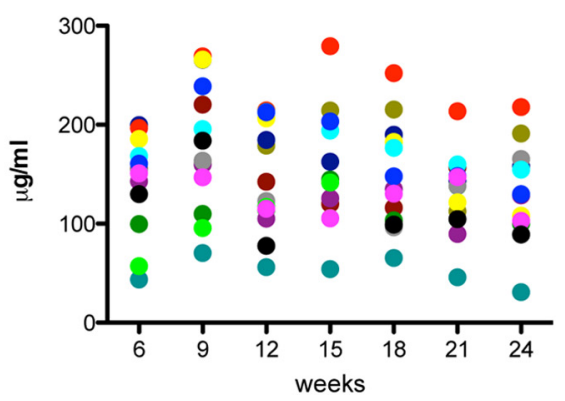

Figure 2. Plasma antibody titers in passively immunized $\alpha$-syn tg mice. Antibody titers ( $\mu \mathrm{g} / \mathrm{ml})$ determined by ELISA in $\alpha$-syn $\operatorname{tg}$ mice immunized with the $C \mathrm{~T} \alpha$-syn antibodies $9 \mathrm{E} 4,1 \mathrm{H7}, 5 \mathrm{C} 1$, or $5 \mathrm{D} 12$. For each antibody, different groups of mice were used and individual animals within each group are represented by different colors. Antibody titers were measured every 3 weeks.

vibratome sections. Sections were incubated overnight at $4^{\circ} \mathrm{C}$ with either a polyclonal antibody against total $\alpha$-syn (1:500, affinity-purified rabbit polyclonal; Millipore; Masliah et al., 2000), an antibody against CT- $\alpha$ syn (SYN105; Games et al., 2013), an anti-GFAP antibody (1:500; Millipore) or an anti-Ibal antibody (1:2000; Wako), followed by secondary antibodies tagged with FITC or biotinylated (1:100; Vector Laboratories), avidin D-HRP (1:200, ABC Elite; Vector Laboratories) and detection with the Tyramide Signal Amplification-Direct (Red) system (1:100; NEN Life Sciences) or 3,3'-diaminobenzidine (Masliah et al., 2011). All sections were processed simultaneously under the same conditions and experiments were performed in triplicate to assess the reproducibility of results.

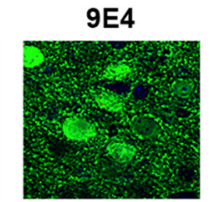

5D12

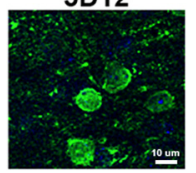

Stereological analysis and image analysis of neocortical and hippocampal intraneuronal FL- $\alpha$-syn and CT- $\alpha$-syn immunoreactivity was conducted by the dissector method using the Stereo-Investigator System (MBF Bioscience) and the results were averaged and expressed as cell counts per $0.1 \mathrm{~mm}^{3}$. Neocortical and hippocampal FL- $\alpha$-syn and CT- $\alpha$-syn immunoreactive neuropil was assessed in digital images analyzed with ImageQuant software (GE Life Sciences) by selecting an area to exclude cell bodies, setting the threshold levels, and expressing the data as pixel intensity (arbitrary units).

Double immunolabeling. To determine the colocalization between CT- $\alpha$-syn and the neurofilament marker SMI312, double-labeling experiments were performed as described previously (Spencer et al., 2009). Vibratome sections were immunolabeled with the CT- $\alpha$-syn antibody SYN105 (1:500; Millipore) and the $\alpha$-syn immunoreactive structures were detected with the Tyramide Signal AmplificationDirect (Red) system (1:100; NEN Life Sciences). SMI312 was detected with an FITC-tagged antibody (1:75; Vector Laboratories). Colocalization experiments for assessing propagation of $\alpha$-syn were performed with antibodies against FL- $\alpha$-syn or CT- $\alpha$-syn detected with tyramide red in B103 cells expressing GFP. All sections were processed simultaneously under the same conditions and experiments were performed in triplicate to assess the reproducibility of results. Sections were imaged with a Zeiss $63 \times$ (numerical aperture 1.4) objective on an Axiovert 35 microscope (Zeiss) with an attached MRC1024 LSCM (laser scanning confocal microscope) system (Bio-Rad; Masliah et al., 2000).

Lentiviral-vector-mediated expression of $F L$ $\alpha$-syn and CT- $\alpha$-syn and in vitro propagation assay. The full-length human $\alpha$-syn cDNA was cloned into the pcDNA3.1V5His vector, which adds the V5 epitope tag and 6XHis tag to the CT of the $\alpha$-syn cDNA. Similarly, the CTtruncated human $\alpha$-syn (1-114) was also cloned into the pcDNA3.1V5His vector. The cDNAs containing either FL- $\alpha$-syn or CT- $\alpha$ syn plus the V5-His tag were cloned into the third-generation self-inactivating lentiviral vector plasmid (Tiscornia et al., 2006) with the CMV promoter, producing the vectors $\mathrm{LV}-\alpha$ syn-V5 and LV-CT- $\alpha$-syn-V5. The lentiviral vector expressing GFP has been described previously (Bar-On et al., 2008). Lentiviruses were prepared by transient transfection in HEK293T cells (Tiscornia et al., 2006).

For studying calpain-1 release, B103 neuronal cells were infected with $\mathrm{LV}-\alpha$-syn-V5 and allowed to express the construct up to $72 \mathrm{~h}$. Cytosolic and membrane fractions and supernatant media were analyzed for the presence of FL- $\alpha$-syn (rabbit polyclonal, 1:1000; Millipore), CT- $\alpha$-syn (SYN105), and calpain-1 (1:1000; Abcam) by immunoblot.

For propagation experiments, B103 neuronal cells were plated on 10 $\mathrm{cm}$ tissue culture dishes and infected with LV- $\alpha$-syn-V5, LV-CT- $\alpha$ syn-V5 or control lentivirus (LV-GFP) at a multiplicity of infection of 20. Forty-eight hours after infection, cells were collected and replated in cell culture inserts (PET membrane, $0.4 \mu \mathrm{m}$ pore size, Falcon; Fisher Scientific) at a density of $1 \times 10^{5}$ cells. Recipient (uninfected) B103 neuronal 
A

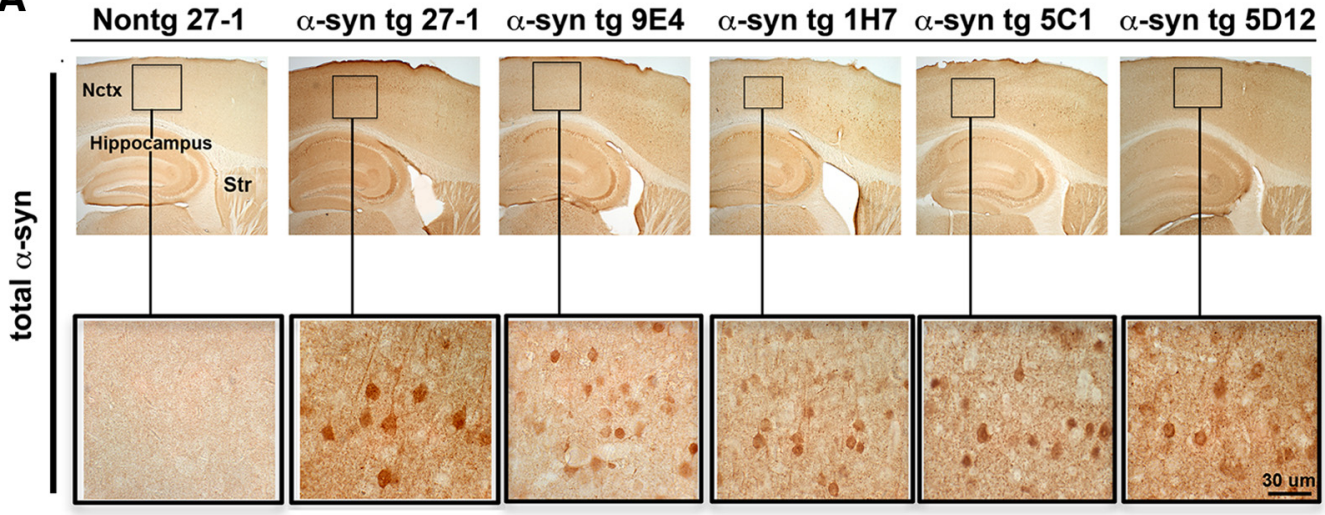

B

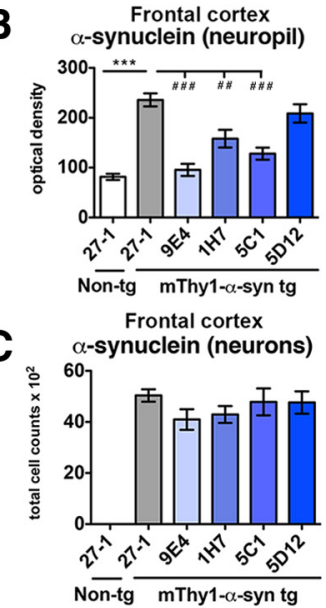

Frontal cortex

$E$

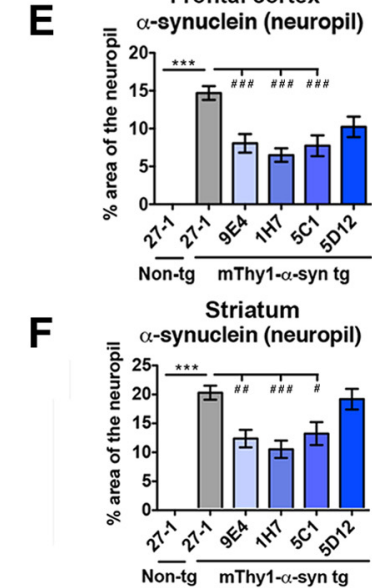

$\mathbf{F}$

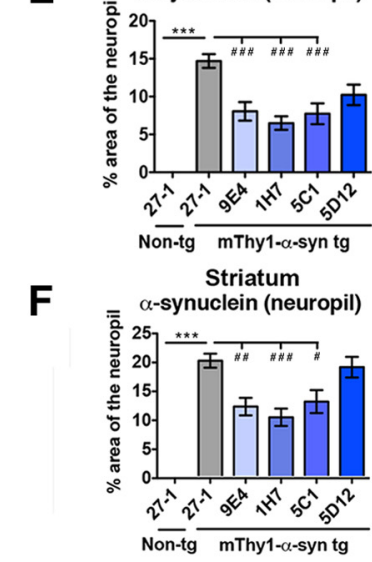

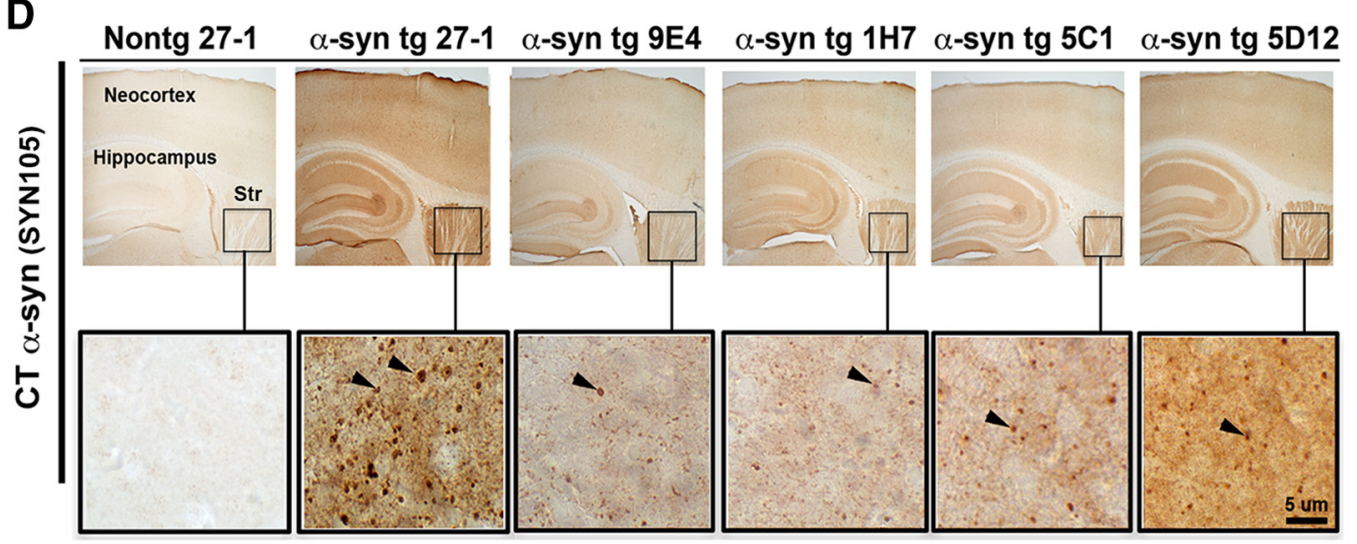

Figure 3. Immunohistochemical analysis of passively immunized $\alpha$-syn tg mice with antibodies against FL $\alpha$-syn or CT-truncated $\alpha$-syn. To determine the effects of passive immunization on FL- $\alpha$-syn $(\boldsymbol{A}-\boldsymbol{C})$ or $(\mathrm{T}-\alpha$-syn $(\boldsymbol{D}-\boldsymbol{F})$ accumulation, immunohistochemical analysis using species-specific antibodies was conducted. $\boldsymbol{A}$, Top, Images of the neocortex and hippocampus of non-tg mice immunized with control antibody 27-1 and $\alpha$-syn tg mice immunized with antibodies 27-1, 9E4, 1H7, 5C1, or 5D12. Sections were immunolabeled with an antibody against FL- $\alpha$-syn. Bottom, Higher-magnification images of the neocortex of the sections above. Scale bar, $30 \mu \mathrm{m}$. B, Analysis of the levels of $\alpha$-syn immunoreactivity in the neocortex, measured as optical density in sections labeled with the FL- $\alpha$-syn antibody. C, Stereological analysis of the numbers of neocortical $\alpha$-syn-immunoreactive neurons stained with the FL- $\alpha$-syn antibody. $\boldsymbol{D}$, Top, Images of the neocortex, hippocampus, and striatum of non-tg mice immunized with control antibody 27-1 and $\alpha$-syn tg mice immunized with antibodies 27-1, 9E4, 1H7, 5C1, or 5D12. Sections were immunolabeled with the antibody SYN105 against CT- $\alpha$-syn. Bottom, Higher-magnification images of the striatum of the sections showed above. Arrows highlight $\alpha$-syn-positive granular-like structures. Scale bar, 5 $\mu \mathrm{m} . \boldsymbol{E}$, Analysis of the levels of $\alpha$-syn immunoreactivity in the neocortex, measured as the percentage of neuropil area stained in sections labeled with the (T- $\alpha$-syn antibody. $\boldsymbol{F}$, Analysis of the levels of $\alpha$-syn immunoreactivity in the striatum, measured as the percentage of neuropil area stained in sections labeled with the CT- $\alpha$-syn antibody. Error bars represent \pm SEM. ${ }^{* * *} p<0.001$ when comparing non-tg 27-1-immunized mice to $\alpha$-syn tg 27-1-immunized mice; \#p <0.05; \#\#p <0.01; \#\#\#p 0.001 comparing $\alpha$-syn tg mice immunized with 27-1 with $\alpha$-syn tg mice immunized with 9E4, $1 \mathrm{H} 7$, or $5 \mathrm{C} 1$.

cells were plated at a density of $1 \times 10^{5}$ cells on poly-lysine (Sigma)-coated glass coverslips in a 12 well plate. Four hours after cells were plated on either the coverslips or cell inserts, cultures were combined so that the $\alpha$-syn-expressing cells (donor) were in the insert separated from the uninfected cells (recipient) plated on a coverslip by the $0.4 \mu \mathrm{m}$ membrane. Antibodies 27-1, 9E4, 1H7, 5C1, or 5D12 were added to the incubation medium (1:100). Twenty-four hours after coculture, immunocytochemistry analysis was performed in the recipient cells.

Statistical analysis. All experiments were performed blind coded and in triplicate. Values in the figures are expressed as means \pm SEM. To determine the statistical significance, values were compared using one-way ANOVA with Tukey-Kramer post hoc test when comparing with the IgG1 control (27-1). Repeated-

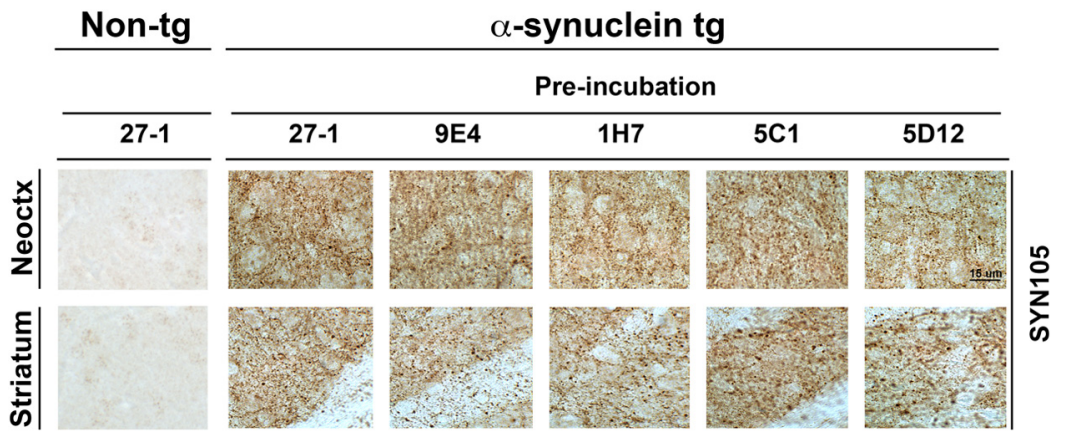

Figure 4. Binding of CT $\alpha$-syn antibodies did not affect SYN105 immunoreactivity in $\alpha$-syn tg mice. To determine whether CT $\alpha$-syn antibody binding blocked the binding of the CT-truncated $\alpha$-syn antibody SYN105, brain sections of non-immunized non-tg or $\alpha$-syn tg mice were preincubated with 27-1,9E4, 1H7, 5C1, or $5 \mathrm{D} 12$ antibodies (1:100) for $1 \mathrm{~h}$ and then immunostained with the CT- $\alpha$-syn antibody SYN105. Representative images from the neocortex and striatum are shown. Scale bar, $15 \mu \mathrm{m}$. 
A

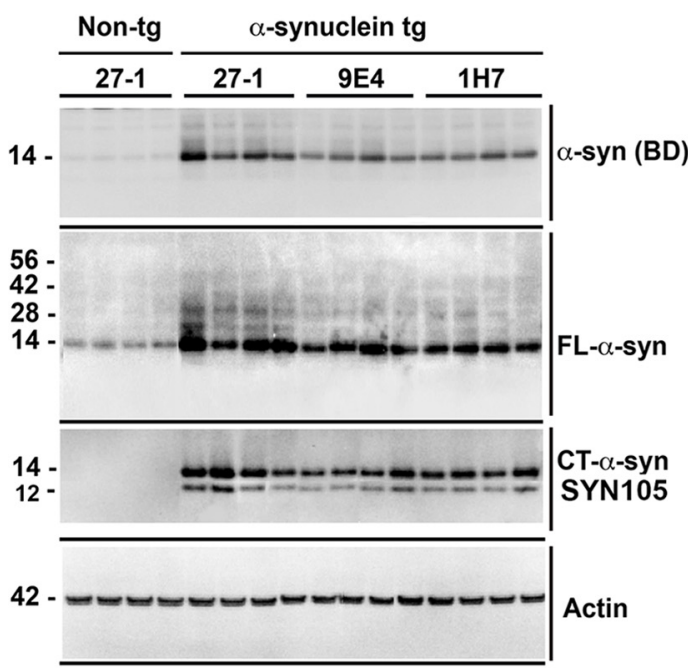

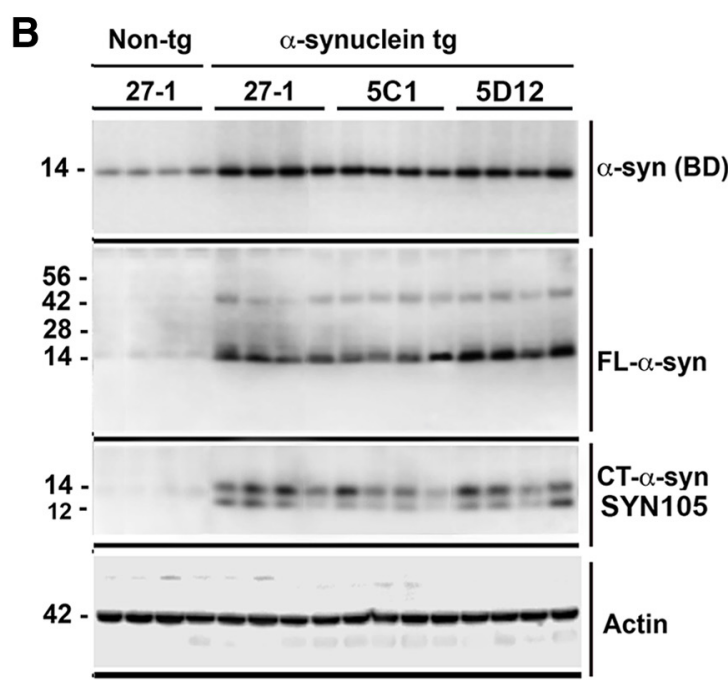

E
C

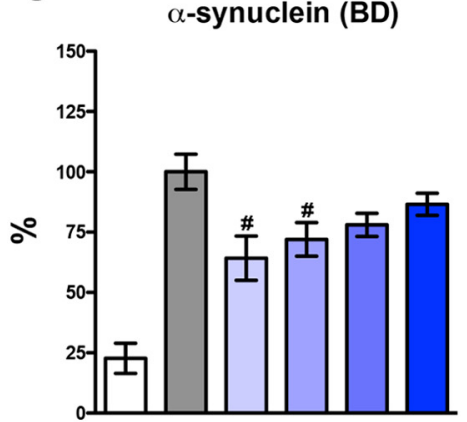

D

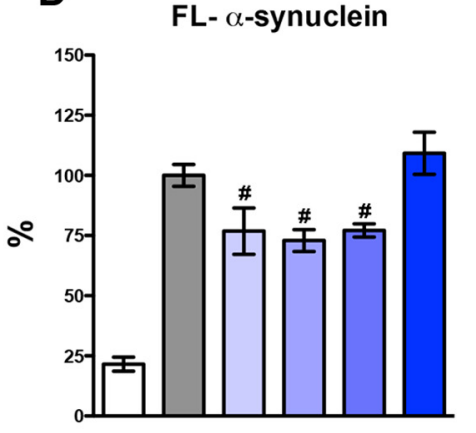

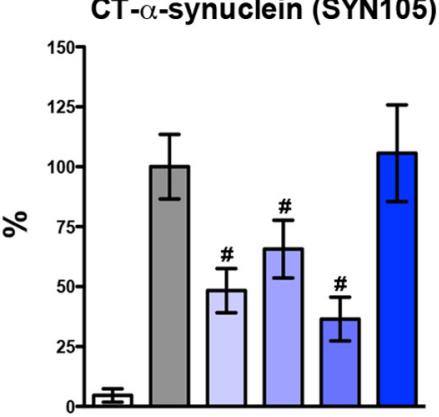

$\square$ Non-tg 27-1

$\alpha$-syn tg 27-1

$\alpha$-syn tg 9E4

$\alpha$-syn tg $1 \mathrm{H} 7$

$\alpha$-syn tg 5C1

$\alpha$-syn tg 5D12

Figure 5. Immunoblot analysis of brain extracts of passively immunized $\alpha$-syn tg mice with antibodies against full-length and CT-truncated $\alpha$-syn. To examine the effects of immunization on $\alpha$-syn protein levels, immunoblot analysis of non-tg mice immunized with 27-1 or $\alpha$-syn tg mice immunized with 27-1, 9E4, 1H7, 5C1, or 5D12 was performed. $A, B$, Protein immunoblots were probed with antibodies against total $\alpha$-syn (BD), FL- $\alpha$-syn, (T- $\alpha$-syn (SYN105), and actin as a loading control. The $14 \mathrm{kDa}$ band is monomeric $\alpha$-syn and the $12 \mathrm{kDa}$ band is (T- $\alpha$-syn. Higher molecular weight bands correspond to different $\alpha$-syn oligomers. C, Densitometric analysis of the $\alpha$-syn immunoreactive bands as detected by the total $\alpha$-syn antibody (BD). $\boldsymbol{D}$, Densitometric analysis of the $\alpha$-syn immunoreactive bands as detected by the FL- $\alpha$-syn antibody. E, Densitometric analysis of the $\alpha$-syn immunoreactive bands as detected by the (T- $\alpha$-syn antibody (SYN105). Error bars represent \pm SEM. (\#) indicates $p<0.05$ when comparing $\alpha$-syn tg mice immunized with 27-1 to $\alpha$-syn tg mice immunized with 9E4, 1H7, or 5C1.

measures two-way ANOVA was used to analyze water maze results when comparing antibody-treated mice with the non-tg or IgG1-treated controls. The differences were considered to be significant at $p<0.05$.

\section{Results}

Passive immunotherapy reduces the accumulation of CT- $\alpha$ syn in the cortex and striatum of mThy1- $\alpha$-syn $\operatorname{tg}$ mice For this study, new antibodies against the CT of $\alpha$-syn were prepared and investigated, including $1 \mathrm{H} 7$ (syn aa 91-99), 5C1 (syn aa 118-126), and 5D12 (syn aa 118-126; Fig. 1A). The latter two are similar in epitope to our previously described monoclonal antibody 9E4 (Masliah et al., 2011) and were chosen to fully explore the effects of CT $\alpha$-syn antibodies on neuropathology and behavior in a PD mouse model. The 9E4-like analogs 5C1 and 5D12 were raised using 10-mer peptides and have a linear epitope; $1 \mathrm{H} 7$ and 9E4 were raised using FL recombinant $\alpha$-syn. Binding kinetic rates and affinities of the antibodies for $\alpha$-syn were measured by surface plasmon resonance (Biacore). All antibodies had an equilibrium dissociation constant $\left(K_{\mathrm{D}}\right)$ in the nanomolar range. $1 \mathrm{H} 7$ displayed the highest affinity for $\alpha$-syn $\left(K_{\mathrm{D}}=9.6 \mathrm{nM}\right)$ and $5 \mathrm{C} 1$ the lowest $\left(K_{\mathrm{D}}=85.7 \mathrm{nM}\right) ; 9 \mathrm{E} 4$ and $5 \mathrm{D} 12$ showed similar affinity for $\alpha$-syn $\left(K_{\mathrm{D}}=21.2\right.$ and $26.8 \mathrm{nM}$, respectively). To verify the ability of the antibodies to recognize $\alpha$-syn, blots containing brain homogenates from naive non-tg and mThy1- $\alpha$-syn tg mice were probed with the antibodies selected for passive immunization (Fig. $1 B$ ). The $1 \mathrm{H} 7$ antibody recognized a $14 \mathrm{kDa}$ band consistent with monomeric $\alpha$-syn in non-tg and tg mice. Moreover, in the tg mice this antibody also recognized a $12 \mathrm{kDa}$ band, consistent with the $\mathrm{N}$-terminal fragment of $\alpha$-syn following CT truncation, as well as higher-molecularweight bands representing potential oligomers (Fig. 1B). Likewise, the $5 \mathrm{C} 1$ and the $9 \mathrm{E} 4$ antibodies recognized $12 \mathrm{kDa}, 14 \mathrm{kDa}$, and higher-molecular-weight bands in the tg mice (Fig. 1). In contrast, the 5D12 antibody recognized mostly the $14 \mathrm{kDa}$ monomer band and some higher-molecular-weight bands (Fig. 1B). By immunohistochemistry, we observed that $1 \mathrm{H} 7$ immunostained neuronal cell bodies and synapses in the brains of mThy1- $\alpha$-syn $\operatorname{tg}$ mice and a similar pattern of immunostaining, but to a lesser extent, was observed with 5C1 and 5D12 (Fig. 1C).

Next, groups of 10-12 mThy1- $\alpha$-syn tg mice were immunized for 6 months with the new antibodies $1 \mathrm{H} 7,5 \mathrm{C} 1$, and 5D12, as well 9E4 (reference control) and 27-1 (nonimmune control). The mThy1- $\alpha$-syn tg mice (line 61; Rockenstein et al., 2002) were selected because they display accumulation of CT- $\alpha$-syn and oligomers in cortical and subcortical regions (Games et al., 2013) accompanied by cortico-limbic degeneration (Price et al., 2010), striato-nigral pathology, and motor deficits (Chesselet et al., 2012). Titers in plasma by ELISA demonstrated constant levels of all 4 antibodies through the 6 months of immunization and, 

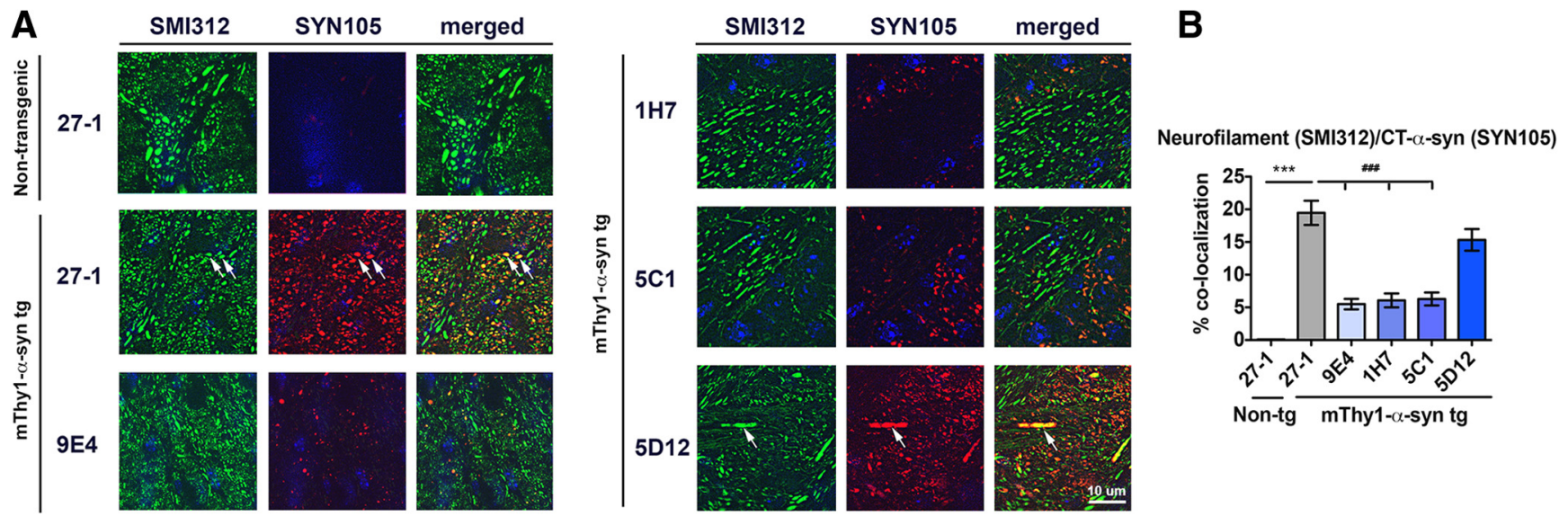

Figure 6. Colocalization of the neurofilament marker SMI312 and the CT- $\alpha$-syn antibody SYN105 was reduced in passively immunized $\alpha$-syn tg mice. To determine whether passive immunization altered the subcellular distribution of (T- $\alpha$-syn, double labeling of brain sections of non-tg mice immunized with 27-1 or $\alpha$-syn tg mice immunized with 27-1, 9E4, 1H7, 5C1, or 5D12 was performed using a neurofilament marker (SMI312) and the CT- $\alpha$-syn antibody SYN105. $A$, Representative confocal images of the neuropil in brain sections from non-tg mice immunized with 27-1 or $\alpha$-syn tg mice immunized with 27-1, 9E4, 1H7, 5C1, or 5D12. Arrows indicate colocalization of the SMI312 signal with CT- $\alpha$-syn in neurofilament-like structures. Scale bar, $10 \mu$ m. $\boldsymbol{B}$, Analysis of the percentage of colocalization between the neurofilament marker SMI312 and the CT- $\alpha$-syn antibody SYN105. Error bars represent \pm SEM. ${ }^{* *} p<0.001$ comparing non-tg $27-1$-immunized mice with $\alpha$-syn tg 27-1-immunized mice. \#\#\# $<0.001$ comparing $\alpha$-syn tg mice immunized with 27-1 with $\alpha$-syn tg mice immunized with 9E4, $1 \mathrm{H7}$, or 5C1.

A
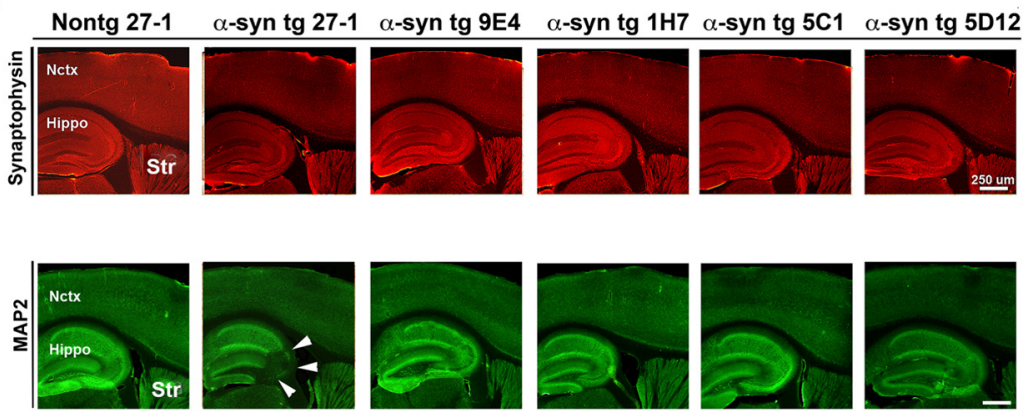

$\mathbf{F}$ Ntg $\alpha$-synuclein tg 27-1 27-1 9E4 $1 \mathrm{H} 7$ 5C1 5D12

95
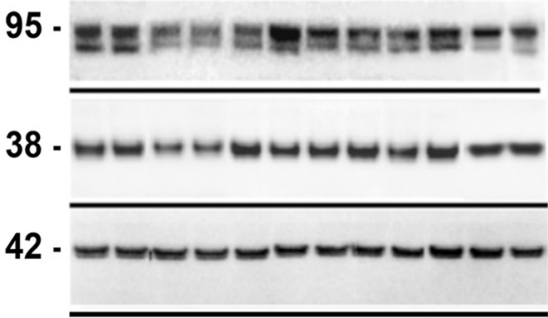

G

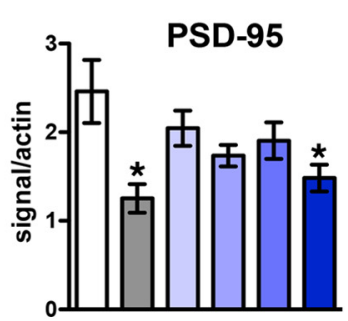

B

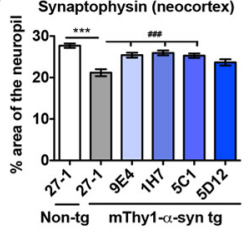

D

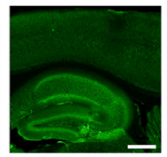

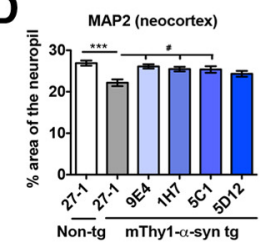

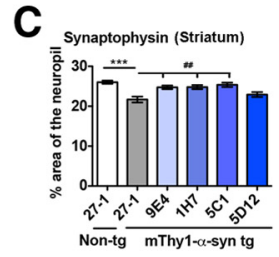

E

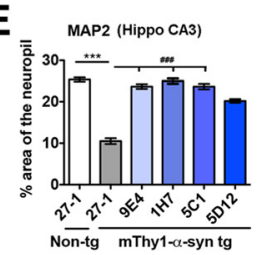

Figure 7. Passive immunization with CT $\alpha$-syn antibodies improved synaptic pathology in $\alpha$-syn tg mice. The effect of passive immunization with CT $\alpha$-syn antibodies on synaptic markers was evaluated in the neocortex, striatum, and hippocampus of non-tg mice immunized with 27-1 or $\alpha$-syn tg mice immunized with 27-1, 9E4, 1H7, 5C1, or 5D12. A, Brain sections were stained with an antibody against synaptophysin (red) or an antibody against MAP2 (green), and representative fluorescence images are shown. Arrows highlight synaptic loss in the hippocampus of $\alpha$-syn tg mice. Scale bar, $250 \mu \mathrm{m} . \boldsymbol{B}$, Analysis in neocortex of the percentage of area of the neuropil stained by the synaptophysin antibody. C, Analysis in striatum of the percentage of area of the neuropil stained by the synaptophysin antibody. $\boldsymbol{D}$, Analysis in neocortex of the percentage of area of the neuropil stained by the MAP2 antibody. $\boldsymbol{E}$, Analysis of the percentage of neuropil stained by the MAP2 antibody in the CA3 area of the hippocampus. $\boldsymbol{F}$, Immunoblot analysis of the synaptic markers PSD-95 and synaptophysin. Actin was used as a loading control. $\mathbf{G}$, Densitometric analysis of the PSD-95-immunoreactive bands. $\boldsymbol{H}$, Densitometric analysis of the synaptophysin-immunoreactive bands. Error bars represent \pm SEM. ${ }^{*} p<0.05$ and ${ }^{* * *} p<0.001$ comparing non-tg $27-1$ immunized mice with $\alpha$-syn tg 27-1-immunized mice; \#p <0.05, \#\#p <0.01, \#\#p <0.001 comparing $\alpha$-syn tg mice immunized with 27-1 to $\alpha$-syn tg mice immunized with 9E4, 1H7, or 5C1.

overall, antibody levels were higher with $1 \mathrm{H} 7$ and $5 \mathrm{C} 1$ than with 9E4 and 5D12 (Fig. 2).

To investigate whether immunotherapy with the new CT $\alpha$-syn antibodies $1 \mathrm{H} 7,5 \mathrm{C} 1$, and 5D12 reduced accumulation of truncated $\alpha$-syn, stereological analysis was performed with antibodies against FL- $\alpha$-syn and CT- $\alpha$-syn (SYN105; Games et al.,
2013; Fig. 3). We observed a trend toward a reduction in number of cells with intraneuronal accumulation of $\alpha$-syn in the temporal cortex of animals treated with 9E4 and 1H7, although those differences were not significant compared with IgG1 (27-1)-treated $\alpha$-syn tg mice (Fig. 3B). However, measurements of $\alpha$-syn immunoreactivity in the neuropil showed a significant reduction in 
A
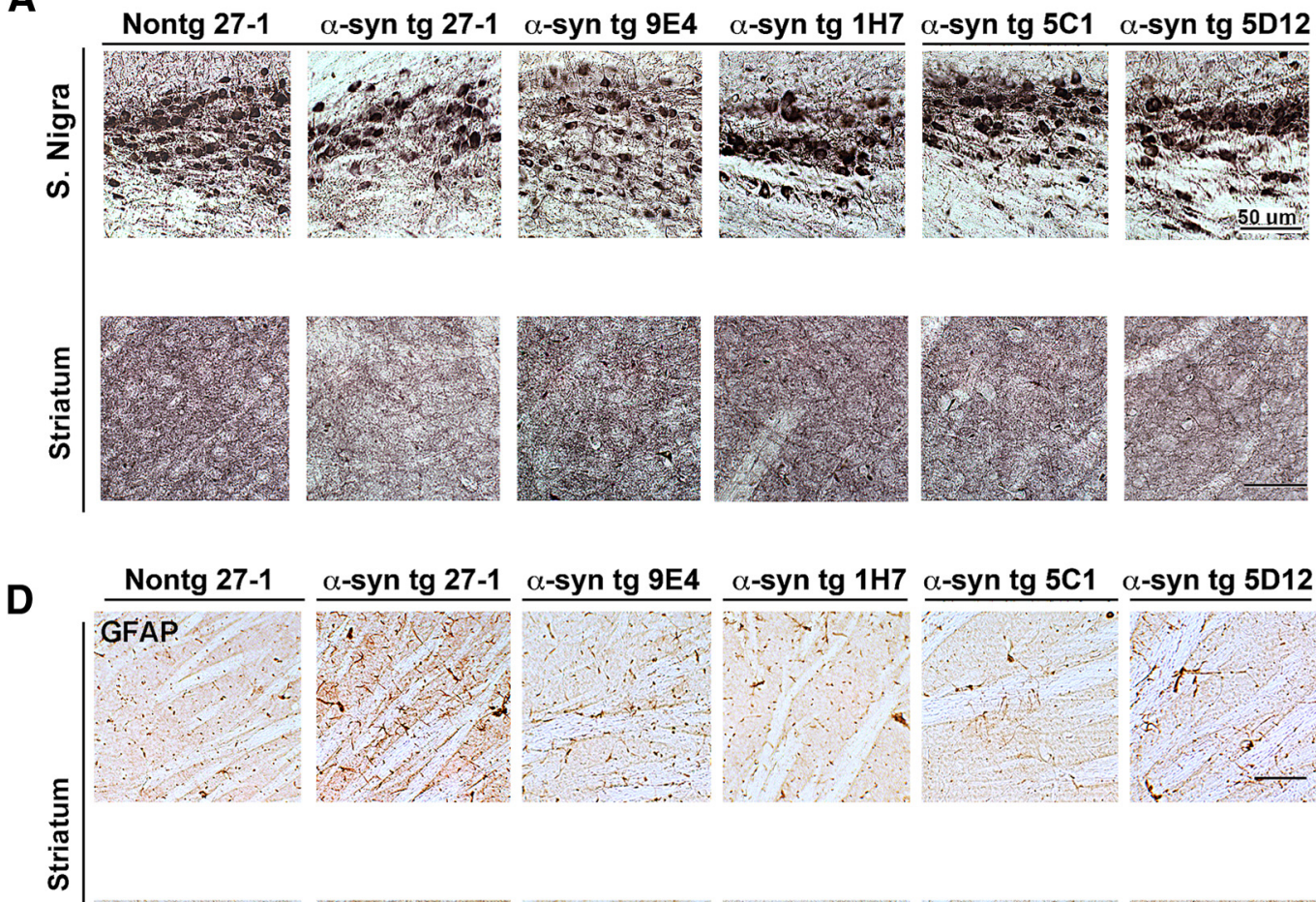

$\alpha$-syn tg 27-1 $\alpha$-syn tg 9E4

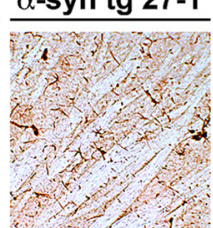

$\alpha-s y n \operatorname{tg} 9 E 4$

$\alpha-s y n \operatorname{tg} 1 \mathrm{H} 7$

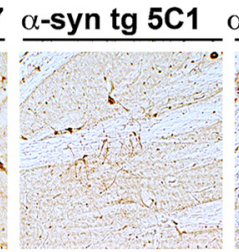

$\alpha-\operatorname{syn} \operatorname{tg} 5 \mathrm{D} 12$

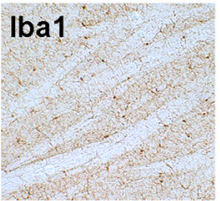

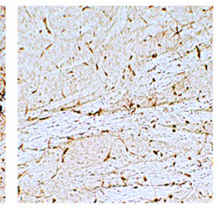
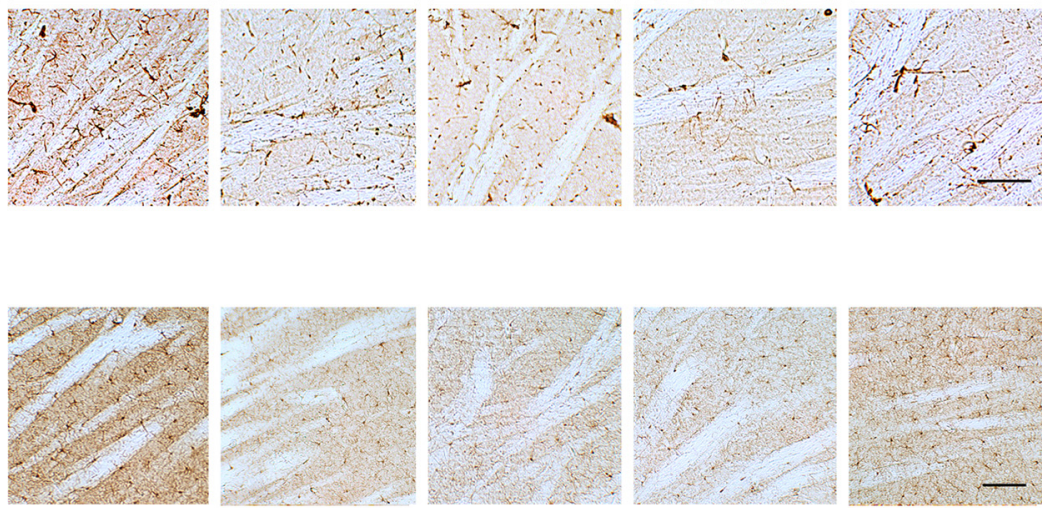

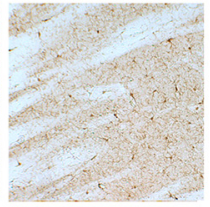

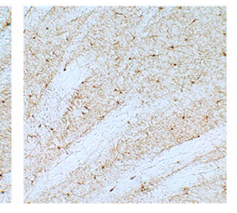

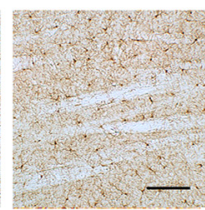

B

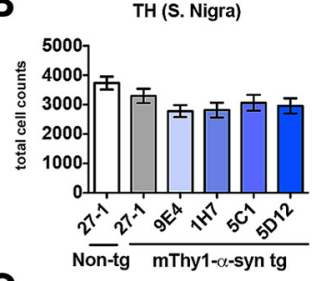

C
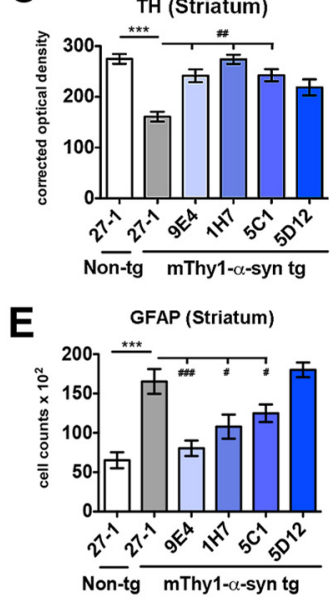

$\mathbf{F}$

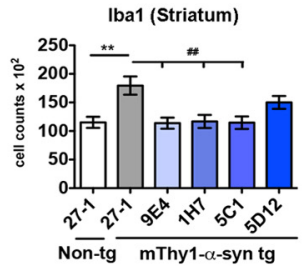

Figure 8. Passive immunization with CT $\alpha$-syn antibodies improved TH pathology and neuroinflammation in the striatum of $\alpha$-syn tg mice. To determine whether immunization with CT $\alpha$-syn antibodies rescued the loss of TH fibers in $\alpha$-syn tg mice, brain sections of non-tg mice immunized with 27-1 or $\alpha$-syn tg mice immunized with 27-1, 9E4, 1H7,5C1, or 5D12 were immunostained with an antibody against TH. A, Representative images of the substantia nigra and the striatum of non-tg mice immunized with 27-1 or $\alpha$-syn tg mice immunized with 27-1,9E4, 1H7, 5C1, or 5D12 immunostained with an antibody against TH. Scale bar, $50 \mu \mathrm{m}$. B. Cell counts of TH-immunoreactive neurons in substantia nigra. C, Optical density analysis of TH immunoreactivity in striatum. $\boldsymbol{D}$, To determine whether immunization with CT $\alpha$-syn antibodies reduced neuroinflammation in $\alpha$-syn tg mice, brain sections of non-tg mice immunized with 27-1 or $\alpha$-syn tg mice immunized with $27-1,9 E 4,1 \mathrm{H7}, 5 \mathrm{C1}$, or 5D12 were immunostained with an antibody against GFAP (astrocytes) or lba1 (microglia). Representative images of the striatum are shown. Scale bar, $250 \mu \mathrm{m}$. E, Cell counts of GFAP-immunoreactive cells in striatum. $\boldsymbol{F}$, Cell counts of Iba1-immunoreactive cells in striatum. Error bars represent \pm SEM. ${ }^{* *} p<0.01$ and ${ }^{* * *} p<0.001$ comparing non-tg 27-1-immunized mice with $\alpha$-syn tg 27-1-immunized mice; \#p $<0.05$, \#\#p <0.01, \#\#\#p $<0.001$ comparing $\alpha$-syn tg mice immunized with 27-1 with $\alpha$-syn tg mice immunized with 9E4, $1 \mathrm{H7}$, or 5C1.

animals treated with the antibodies 9E4, 1H7, and 5C1, but not with 5D12, compared with 27-1-treated $\alpha$-syn tg mice (Fig. 3C). Immunohistochemical analysis with the antibody SYN105 against CT- $\alpha$-syn, which recognizes abnormal $\alpha$-syn aggregates in the neuropil (Games et al., 2013), showed a significant reduction of these aggregates in both temporal cortex and striatum in the $\alpha$-syn tg mice treated with the 9E4, 1H7, and 5C1 antibodies compared with $\alpha$-syn tg mice treated with the IgG1 control 27-1 (Fig. $3 E, F)$. Treatment with the antibody 5D12 resulted in a significant reduction of CT- $\alpha$-syn in neocortex, but not in striatum (Fig. $3 E, F)$. Given that mice were immunized with antibodies against the CT of $\alpha$-syn and sections were probed with the SYN105 antibody, it could be argued that the reduced immunoreactivity observed in the treated mice could be the result of antibodies against the CT of $\alpha$-syn blocking the binding of SYN105. To test this possibility, brain sections of untreated $\alpha$-syn tg mice were preincubated with $27-1,9 \mathrm{E} 4,1 \mathrm{H} 7,5 \mathrm{C} 1$, or $5 \mathrm{D} 12$ (1:100) and then probed with SYN105 (1:1000; Fig. 4). Preincubation with CT $\alpha$-syn antibodies did not prevent the binding of SYN105, thus confirming that the reduction observed after passive immunization is not due to antibodies blocking SYN105 binding. Furthermore, the antibodies did not recognize endogenous murine $\alpha$-syn in non-tg animals (Fig. 4), suggesting that they are specific for human $\alpha$-syn.

To corroborate the immunohistochemical results by an independent method, we performed immunoblot analysis using two commercial polyclonal antibodies against FL- $\alpha$-syn and the antibody SYN105 against CT- $\alpha$-syn (Fig. 5). This analysis showed that, compared with $\alpha$-syn tg animals treated with 27-1 (control IgG1), mice immunized with 9E4, $1 \mathrm{H} 7$, and $5 \mathrm{C} 1$, but not $5 \mathrm{D} 12$, displayed reduced levels of FL- $\alpha$-syn ( $14 \mathrm{kDa})$ and CT- $\alpha$-syn (12 $\mathrm{kDa}$ ) in brain homogenates (Fig. 5). Together, these results show that $1 \mathrm{H} 7$ and $5 \mathrm{C} 1$ show activity similar to $9 \mathrm{E} 4$ at reducing the accumulation of CT- $\alpha$-syn in the tg mice.

Reduced accumulation of CT- $\alpha$-syn in immunized mThy1- $\alpha$ syn tg mice ameliorated the neurodegenerative pathology We have shown previously that the SYN105 antibody can detect CT-truncated neurotoxic $\alpha$-syn aggregates in dystrophic neurites in the $\alpha$-syn tg mice, and this pathology is similar to what we observed in the brains of DLB/PD patients (Games et al., 2013). To determine whether passive immunization reduced accumula- 
tion of $\alpha$-syn in the axons, doublelabeling studies were performed with a monoclonal antibody against neurofilaments (SMI312) and the SYN105 antibody (Fig. 6A). In 27-1-treated $\alpha$-syn tg mice, there was extensive colocalization of SYN105 immunoreactivity in the axons. Treatment with 9E4, 1H7, and to a lesser extent $5 \mathrm{C} 1$, reduced the percentage of axons in the striatum displaying accumulation of CT- $\alpha$-syn, whereas 5D12 had no significant effect (Fig. 6B). Therefore, passive immunization with CT antibodies was able to reduce the axonal pathology observed in the $\alpha$-syn tg mice.

Next, we investigated whether immunization with the new antibodies against the CT of $\alpha$-syn ameliorated the neurodegenerative alterations in $\alpha$-syn tg mice. Immunohistochemical analysis demonstrated that levels of synaptophysin, a presynaptic protein, and MAP2, a dendritic protein, were reduced in 27-1-treated $\alpha$-syn tg animals compared with non-tg littermates (Fig. 7A). Immunization with 9E4, 1H7, and 5C1, but not 5D12, significantly increased the immunoreactivity for both synaptophysin and MAP2 in neocortex and striatum of $\alpha$-syn tg animals compared with 27-1-treated control, to levels not significantly different from non-tg mice (Fig. $7 B-D$ ). Immunohistochemistry results were further confirmed by immunoblot (Fig. $7 F-H$ ). Levels of synaptophysin were reduced in the 27-1-treated $\alpha$-syn tg animals, and vaccination with all antibodies except 5D12 significantly restored synaptophysin to levels similar to non-tg animals (Fig. $7 \mathrm{H}$ ). Furthermore, levels of the postsynaptic density protein PSD-95 mimicked the results obtained with synaptophysin (Fig. 7G), confirming the restorative effects of the $\mathrm{CT}$ antibodies in the synaptic structure.

Parkinsonian features have been related to the loss of dopaminergic neurons in the substantia nigra pars compacta and of dopaminergic input to the striatum (Halliday, 2007). To investigate the effects of passive immunization with the CT $\alpha$-syn antibodies on tyrosine hydroxylase (TH) levels, immunohistochemistry was performed (Fig. 8A). Immunization with 9E4, $1 \mathrm{H} 7,5 \mathrm{C} 1$, and 5D12 did not affect TH levels in the substantia nigra of $\alpha$-syn tg animals significantly (Fig. $8 A, B$ ). However, immunization with 9E4, 1H7, and 5C1 prevented the loss of $\mathrm{TH}$ in the striatum $\alpha$-syn tg animals (Fig. $8 A, C$ ). The same trend was observed with $5 \mathrm{D} 12$, but in this case the increase was not statistically significant.

Finally, we investigated whether passive immunization with CT $\alpha$-syn antibodies had an effect on ameliorating neuroinflammation by assessing astroglial and microglial cell counts in $\alpha$-syn tg animals treated with vehicle or with antibodies (Fig. $8 D-F)$. mThyl- $\alpha$-syn tg mice showed significant astrogliosis (GFAP) and microgliosis (Iba1) compared with non-tg controls, observed as an increase in glial cell counts in striatum (Fig. 8 E, F). Passive immunization with $9 \mathrm{E} 4,1 \mathrm{H} 7$, or $5 \mathrm{C} 1$ significantly reduced glial cells numbers to values similar to those observed in non-tg animals (Fig. 8E,F), whereas 5D12 had no significant effect. These results suggest that passive immunotherapy with CT $\alpha$-syn antibodies may also reduce the neuroinflammation associated with $\alpha$-syn toxicity.

\section{Passive immunization with $\mathrm{CT}$ antibodies reduces the behavioral alterations in mThyl- $\alpha$-syn tg mice}

To evaluate the effects of passive immunization with the $\alpha$-syn antibodies on memory and learning, mice were tested in the water maze after the immunization period. During the initial training part of the test, when the platform was visible (days 1-3), all groups performed at comparable levels as determined by repeated-measures two-way ANOVA (data not shown). After the cued platform session, the mice underwent $4 \mathrm{~d}$ of testing, during which time the platform was submerged and hidden from view (days 4-7). On the first day of testing with the hidden platform, all groups performed comparably, indicating that that were all able to swim and locate the platform (Fig. 9A). Over the next $3 \mathrm{~d}$ of testing, the performance of the non-tg mice improved in terms of the distance of their swim path and the time taken to locate the platform. In contrast, the performance of the 27-1-treated $\alpha$-syn tg mice did not improve to the same extent (Fig. 9A) and a significant difference was observed between the 27-1-treated $\alpha$-syn tg mice and non-tg mice. These results indicate that the $\alpha$-syn tg mice have a deficit in the learning and memory skills associated with this task. Mice immunized with the 9E4, 1H7, and 5C1 antibodies took a significantly shorter path and time to locate the hidden platform compared with 27-1-treated $\alpha$-syn tg mice (Fig. $9 A$ ), indicating that passive immunization with those antibodies was able to ameliorate the memory and learning deficits observed in the 27-1-treated $\alpha$-syn tg mice. The time taken for the 9E4-, 1H7-, and 5C1-immunized mice to find the submerged platform did not differ significantly from that of the non-tg mice. In addi- 
A

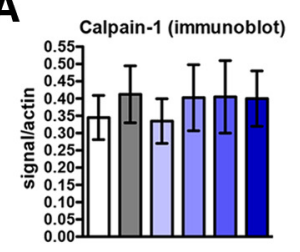

B

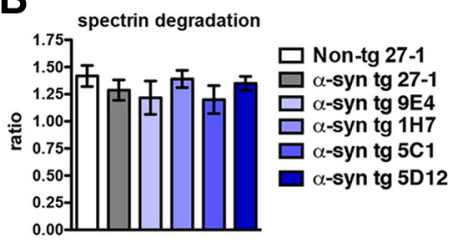

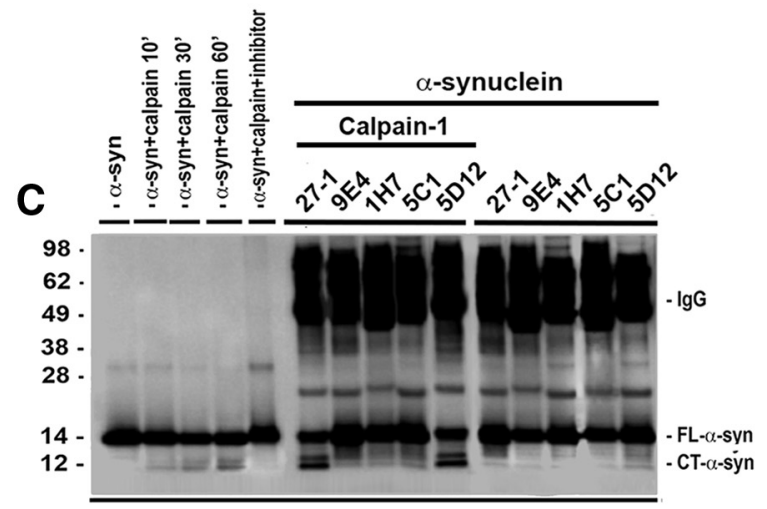

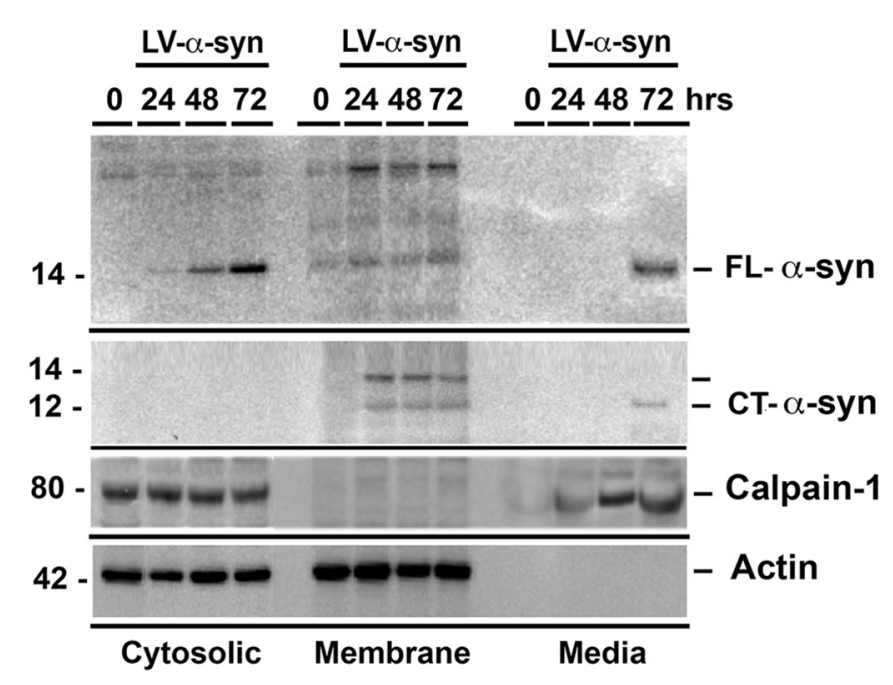

Figure 10. Effect of $\mathrm{CT} \alpha$-syn antibodies on calpain-1 levels and activity and $\alpha$-syn-dependent release of calpain- 1 to the extracellular compartment. To investigate whether changes in CT- $\alpha$-syn levels were associated with changes in enzymatic $\alpha$-syn CT truncation, calpain-1 levels and activity were analyzed. $\boldsymbol{A}$, Calpain-1 levels were measured by immunoblot in brains of non-tg mice immunized with 27-1 or $\alpha$-syn tg mice immunized with 27-1, 9E4, 1H7, 5C1, or 5D12. Error bars represent \pm SEM. $B$, As a control, calpain-1-mediated spectrin degradation was measured in brains of non-tg mice immunized with 27-1 or $\alpha$-syn tg mice immunized with 27-1, 9E4, 1H7, 5C1, or 5D12. Results are expressed as the densitometry ratio between degraded spectrin ( $\approx 150 \mathrm{kDa}$ ) and nondegraded spectrin $(240 \mathrm{kDa}$ ). Error bars represent \pm SEM. C, Activity of calpain- 1 was measured by analyzing the digestion rate of $1 \mu \mathrm{g}$ of recombinant $\mathrm{FL}-\alpha$-syn using $0.2 \mathrm{U}$ of calpain-1 and results were visualized by immunoblot. Control experiments included incubation with the calpain-1 inhibitor Calpeptin at $40 \mu \mathrm{m}$. The $14 \mathrm{kDa}$ band is monomeric $\alpha$-syn and the $12 \mathrm{kDa}$ band is (T- $\alpha$-syn. D, Location of $\alpha$-syn and calpain-1 and their release to the extracellular medium was analyzed in B103 cells $0,24,48$, and $72 \mathrm{~h}$ after infection with a lentiviral construct expressing human $\mathrm{FL}-\alpha$-syn. Protein immunoblots were probed with antibodies against FL- $\alpha$-syn, CT- $\alpha$-syn (SYN105), and calpain- 1 and actin was used as a loading control. The $14 \mathrm{kDa}$ band is monomeric FL- $\alpha$-syn and the $12 \mathrm{kDa}$ band is CT- $\alpha$-syn.

tion, $\alpha$-syn tg mice immunized with 9E4, 1H7, and 5C1, but not 5D12, spent longer periods in the target area compared with 271 -treated $\alpha$-syn tg mice, as determined by one-way ANOVA (Fig. 9B). Importantly, the time spent in the correct quadrant by $\alpha$-syn tg mice immunized with the 9E4, 1H7, and 5C1 antibodies did not differ from that of the non-tg controls (Fig. 9B).

We next determined whether motor deficits in $\alpha$-syn tg mice can be modified by passive immunotherapy. Transgenic and non-tg controls mice were tested for motor performance and coordination on the transversal round beam by recording errors per step. Transgenic mice had significantly more errors in the beam test compared with non-tg control mice, both treated with the 27-1 IgG1 control antibody, consistent with previous reports (Fleming et al., 2004). Conversely, mice immunized with 9E4 and $1 \mathrm{H} 7$ antibodies performed significantly better than $\alpha$-syn tg mice treated with 27-1 (Fig. 9C). Mice immunized with 5C1 and 5D12 did not show significant improvement compared with 27-1treated tg mice. Interestingly, mice treated with anti- $\alpha$-syn antibodies presented a trend to fewer errors than non-tg animals treated with 27-1, although the differences were not significant (Fig. 9C). The performance of mice in the beam test did not appear to be a factor of body weight (Fig. 9D). Together, behavior analysis results confirm that CT $\alpha$-syn antibodies improve memory and motor deficits in this $\alpha$-syn tg model of PD/DLB.

\section{CT $\alpha$-syn antibodies block cleavage of $\alpha$-syn by calpain- 1}

Previous studies have shown that CT truncation of $\alpha$-syn promotes aggregation and toxicity (Murray et al., 2003; VolpicelliDaley et al., 2011). Because we found reduced CT- $\alpha$-syn in the immunized $\alpha$-syn tg mice, it follows that the CT antibodies might be blocking the machinery that results in truncation of $\alpha$-syn. To test this hypothesis, we analyzed expression levels and activity of one of the proteases capable of truncating the CT of $\alpha$-syn (Dufty et al., 2007). We chose calpain-1 because cleavage by this enzyme occurs exclusively within the CT region (Mishizen-Eberz et al., 2005), probably due to this region remaining flexible and exposed to proteases. Calpain-cleaved $\alpha$-syn species colocalize with activated calpain in Lewy bodies and Lewy neurites, suggesting a link between calpain cleavage and $\alpha$-syn aggregation and pathology (Dufty et al., 2007; Games et al., 2013).

By immunoblot, it was determined that immunotherapy had no effects on levels of calpain-1 immunoreactive band or calpain1-mediated spectrin degradation in vivo (Fig. 10A,B). We then investigated the possibility that the antibodies might be blocking the site of $\alpha$-syn CT cleavage. For this purpose, recombinant $\alpha$-syn was digested with calpain-1 in the presence of the CT antibodies. After 10 min of incubation, calpain- 1 degraded $\alpha$-syn, resulting in the formation of bands of $\sim 8-12 \mathrm{kDa}$ detectable with the SYN105 antibody; the calpain-1 inhibitor Calpeptin blocked this effect (Fig. 10C). Preincubation of $\alpha$-syn with the 9E4, 1H7, and $5 \mathrm{C} 1$ antibodies prevented calpain-1 cleavage similar to the calpain-1 inhibitor. 5D12 also blocked calpain-1 cleavage, but to a lesser extent. In contrast, pretreatment with the control antibody 27-1 did not prevent calpain-1 cleavage (Fig. 10C). These results suggest that the mechanism of action of $\mathrm{CT}$ antibodies might involve the protection of the CT of $\alpha$-syn against enzymatic truncation.

Calpain-1 is normally an intracellular enzyme and, although evidence suggests that anti $\alpha$-syn antibodies can be internalized in neurons overexpressing the protein (Bae et al., 2012), the interaction between $\alpha$-syn and antibodies has been proposed to occur primarily in the plasma membrane or the extracellular space (Dufty et al., 2007; Masliah et al., 2011). Therefore, we investigated possible compartments (intracellular, membrane, or 
A
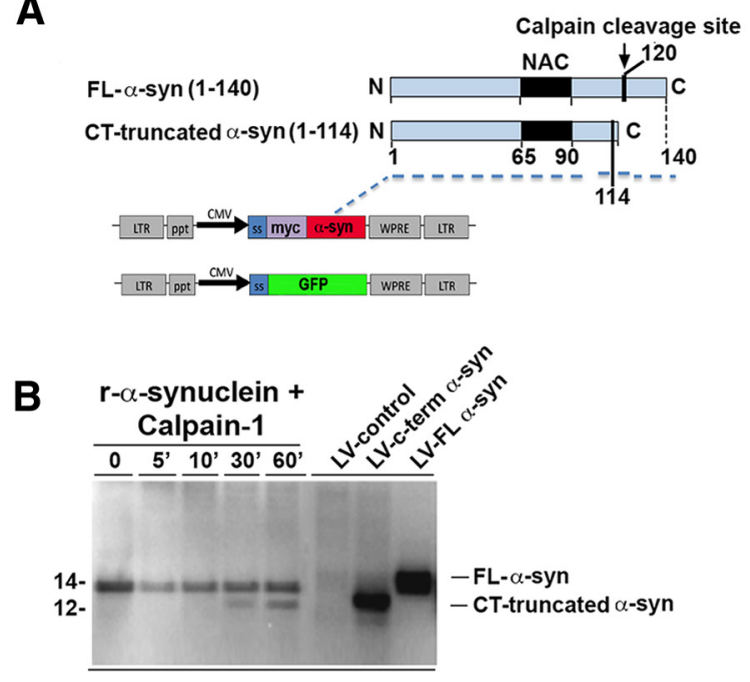

C

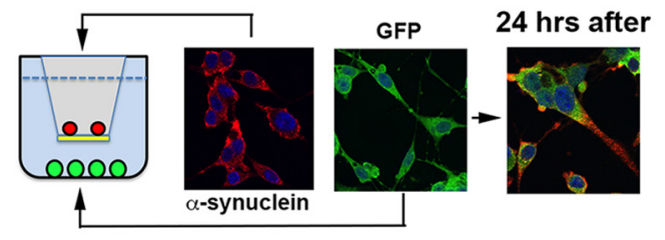

D

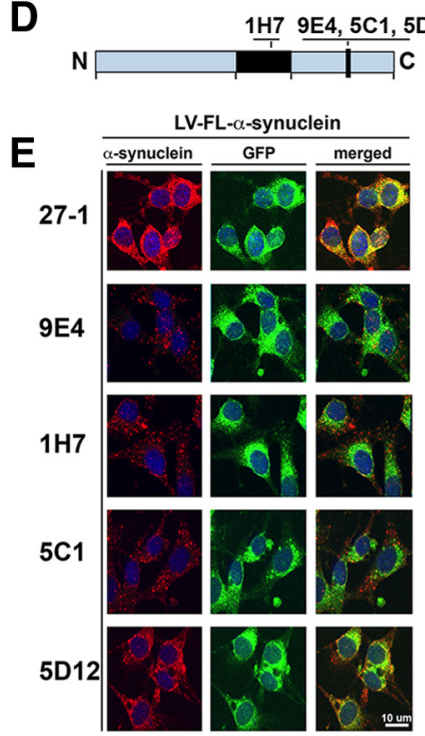

$\mathbf{F}$

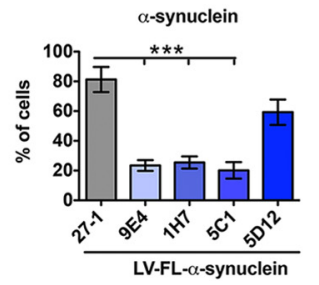

G
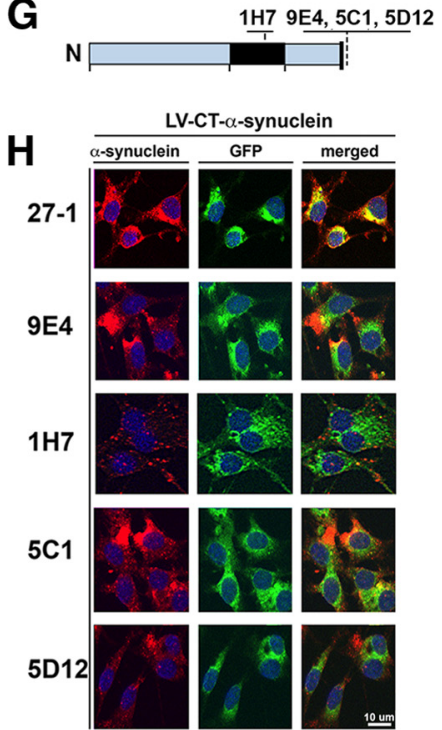

I

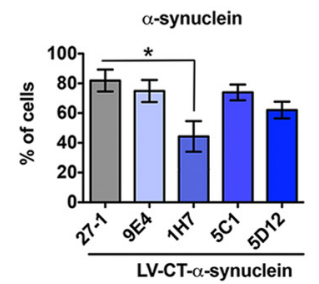

Figure 11. Passive immunization with CT $\alpha$-syn antibodies reduced propagation of FL- $\alpha$-syn and CT- $\alpha$-syn in vitro. $A$, Schematic representation of $\mathrm{FL}-\alpha$-syn, $\mathrm{CT}$ - $\alpha$-syn, and the expression vectors used for lentiviral transfection. The calpain-1 cleavage site is also depicted. B, To analyze the correct expression of FL- $\alpha$-syn or CT- $\alpha$-syn by transfected B103 cells, $\alpha$-syn levels were measured by immunoblot. Digestion of recombinant $\alpha$-syn by calpain- 1 was used as a molecular weight control. The higher-molecular-weight band represents $\mathrm{FL}-\alpha$-syn and the lower-molecularweight band represents (T- $\alpha$-syn. Both proteins are expressed at comparable levels. C, Schematic representation of the in vitro $\alpha$-syn propagation assay, where red represents B103 cells expressing $\alpha$-syn and growing in the insert (donors) and green represents B103 cells expressing GFP and growing in coverslips (recipients). $\alpha$-syn propagation can be analyzed after $24 \mathrm{~h}$ of coincubation by measuring the colocalization between red and green fluorescence in recipient cells. $\mathbf{D}-\mathbf{I}$, To analyze the effect of (T antibodies on $\alpha$-syn propagation, B103 cells expressing FL- $\alpha$-syn or CT- $\alpha$-syn were plated in cell culture inserts and B103 cells expressing GFP were plated in coverslips. Cultures were combined so that the $\alpha$-syn-expressing cells (donor) were growing on an insert separated from the GFP-expressing cells (recipient) plated on a coverslip next to the $0.4 \mu \mathrm{m}$ membrane. The antibodies $27-1,9 \mathrm{E} 4,1 \mathrm{H} 7,5 \mathrm{C} 1$, or 5D12 were added to the incubation medium (1:100) and propagation was measured $24 \mathrm{~h}$ later. $\boldsymbol{D}$, Schematic representation of $\mathrm{FL}-\alpha$-syn and the epitope location of antibodies. $\boldsymbol{E}$, Colocalization images of FL- $\alpha$-syn (red) with GFP (green) in recipient B103 cells. Scale bar, $10 \mu \mathrm{m}$. $\boldsymbol{F}$, Percentage of colocalization between FL- $\alpha$-syn and GFP. G, Schematic representation of CT- $\alpha$-syn and the epitope location of antibodies. The recognition site of 9E4, 5C1, and 5D12 is located downstream of the truncation site of $\alpha$-syn. $\boldsymbol{H}$, Colocalization images of CT- $\alpha$-syn (red) with GFP (green) in recipient B103 cells. Scale bar, $10 \mu \mathrm{M}$. I, Percentage of colocalization between (T- $\alpha$-syn and GFP. Error bars represent \pm SEM. ${ }^{*} p<0.05$ and ${ }^{* * *} p<0.001$ comparing 27-1-treated cells with cells treated with 9E4, 1H7, or $5 \mathrm{C} 1$ antibodies.

extracellular) in which antibodies could block the cleavage of $\alpha$-syn by calpain-1. For that purpose, we infected B103 cells with lentiviruses expressing FL- $\alpha$-syn and analyzed the presence of FL- $\alpha$-syn, CT- $\alpha$-syn, and calpain-1 in cytosol, membrane, and extracellular media 0, 24, 48, and $72 \mathrm{~h}$ after infection (Fig. 10D). The location of FL- $\alpha$-syn 24 and $48 \mathrm{~h}$ after infection was limited to the cytosol and the membrane fraction, and CT- $\alpha$-syn was only observed in the membrane fraction (Fig. 10D). Interestingly, $72 \mathrm{~h}$ after infection FL- $\alpha$-syn could also be observed in the extracellular medium. This release was accompanied by a significant presence of calpain- 1 in the extracellular fraction. CT- $\alpha$-syn was also observed outside of the cell $72 \mathrm{~h}$ after infection. These results show that accumulation of $\alpha$-syn within neuronal cells leads to a release of both $\alpha$-syn and calpain-1 to the extracellular medium and suggest this to be the location where antibodies might be blocking $\alpha$-syn CT truncation.

CT $\alpha$-syn antibodies block the propagation of full-length $\alpha$ syn in vitro

Previous studies have shown that oligomerized $\alpha$-syn (containing CT-truncated fragments) can be released from neurons and propagate to other neuronal and non-neuronal cells (Desplats et al., 2009; Lee et al., 2010). Moreover, recent studies have shown that CT- $\alpha$-syn participates in seeding-mediated propagation (Volpicelli-Daley et al., 2011). This suggests that immunotherapy might work by recognizing extracellular $\alpha$-syn and protecting it from CT truncation. Therefore, we investigated in an in vitro system whether the antibodies against $\alpha$-syn can also prevent the propagation of $\alpha$-syn and if the effect of the antibodies was dependent of the presence of the CT of $\alpha$-syn. To this end, we developed a cell-based model in which B103 neuroblastoma cells are plated in an insert containing a membrane that dives into the chamber (Fig. 11C). The cells growing on the membrane (donor cells) were infected with lentiviral vectors expressing FL or CT$\alpha$-syn tagged with V5, or lentivirus vector alone as a control (Fig. $11 \mathrm{~A}, \mathrm{C})$. In the bottom of the chamber, B103 cells infected with LV-GFP only (recipient cells) were plated onto coverslips (Fig. $11 A, C)$. The expression of the lentiviral vectors was first confirmed by immunoblot comparing the molecular weight of the expressed constructs with the recombinant $\alpha$-syn fragments obtained after calpain-1 digestion (Fig. 11B). Twenty-four hours after coculture, the control IgG (27-1) or the $\alpha$-syn antibodies 

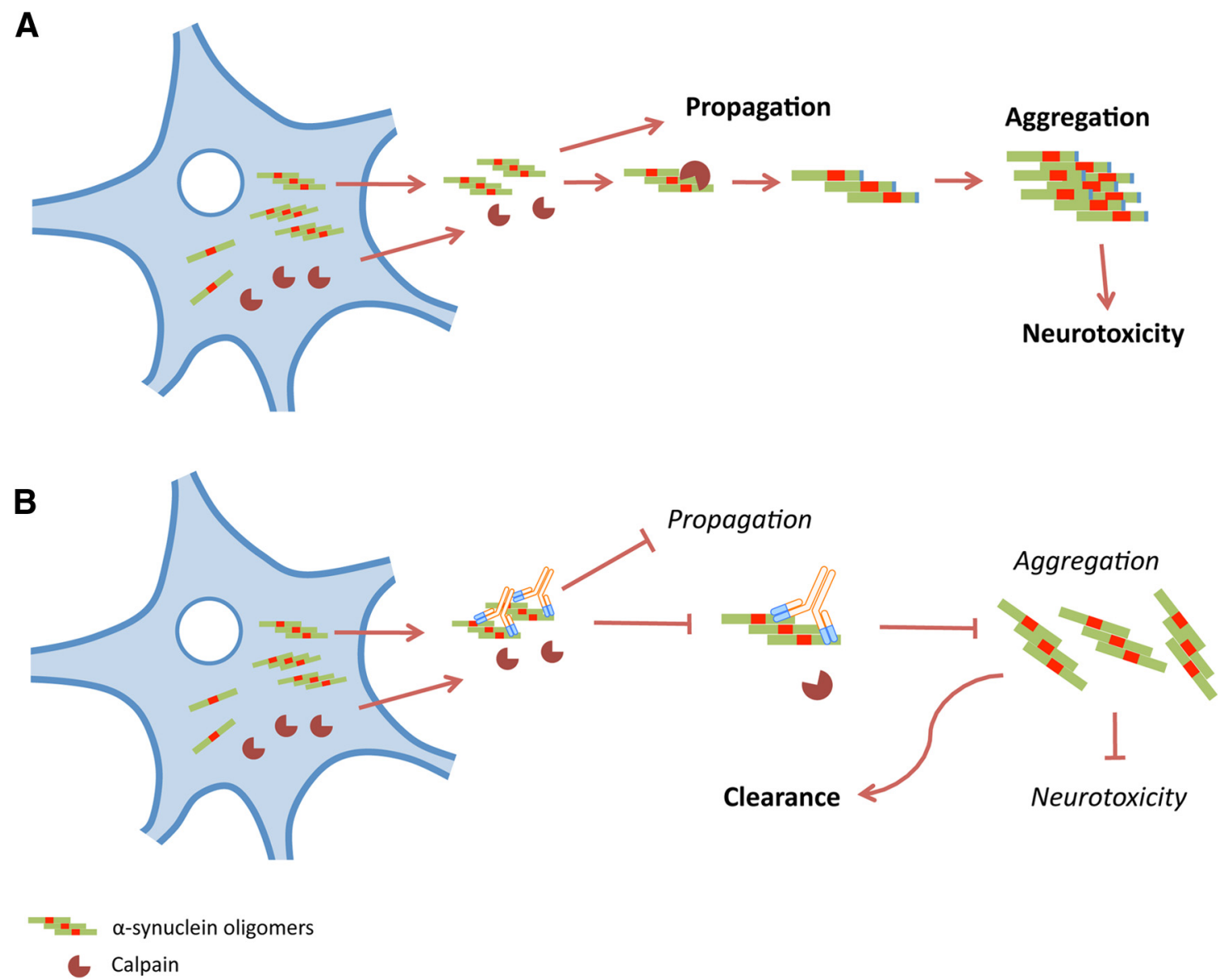

Figure 12. Biological consequences of blocking $\alpha$-syn CT truncation by passive immunotherapy. $\boldsymbol{A}$, Schematic representation of a neuron overexpressing $\alpha$-syn in the $\alpha$-syn tg mouse model. $\alpha$-syn oligomers are released to the extracellular environment, together with calpain-1. Extracellular $\alpha$-syn oligomers can propagate to other neurons and glial cells. Furthermore, $\alpha$-syn oligomers can also be cleaved by calpain-1, generating extracellular CT- $\alpha$-syn, which is more prone to aggregation and subsequent neurotoxicity. $\boldsymbol{B}$, In tg animals immunized with CT $\alpha$-syn antibodies, propagation of extracellular $\alpha$-syn oligomers is inhibited and $\alpha$-syn is protected from CT truncation. The rate of $\alpha$-syn aggregation is thus diminished and $\alpha$-syn oligomers can be effectively directed toward clearance pathways.

(9E4, 1H7, 5C1, and 5D12) were added to wells for $24 \mathrm{~h}$. The recipient cells were then analyzed by immunocytochemistry to estimate the proportion of cells displaying the presence of the FL- $\alpha$-syn. In the experiments with donor cells expressing FL- $\alpha$ syn, $\sim 80 \%$ of the recipient cells treated with the control IgG showed the presence of $\alpha$-syn (Fig. $11 E, F$ ). In contrast, only $20 \%$ of the recipient cells treated with 9E4, 1H7, and 5C1 displayed $\alpha$-syn immunoreactivity (Fig. $11 E, F$ ). For the 5D12 antibody, an average of $65 \%$ of the recipient cells presented $\alpha$-syn immunostaining (Fig. $11 E, F$ ). These results are consistent with the in vivo and calpain-1 digestion studies showing that $1 \mathrm{H} 7$ and $5 \mathrm{C} 1$ reduced $\alpha$-syn pathology and related deficits comparable to 9E4, whereas $5 \mathrm{D} 12$ is less active.

To confirm that the effects of CT antibodies at reducing $\alpha$-syn propagation were dependent on the recognition of the CT domain of $\alpha$-syn, experiments were performed with donor cells expressing CT- $\alpha$-syn (1-114, V5 tagged; Fig. $11 H, I)$. Remarkably, analysis of the GFP-tagged recipient cells showed a similar percentage of cells positive for $\alpha$-syn in wells treated with the control IgG or the 9E4, 5C1, and 5D12 antibodies (Fig. 11 H,I). The $1 \mathrm{H} 7$ antibody (epitope at aa 91-99) was able to reduce the percentage of GFP cells positive for $\alpha$-syn down to $45 \%$ (Fig. $11 H, I)$. Together, these studies support the notion that antibodies against the CT of $\alpha$-syn reduce both the accumulation and propagation of neurotoxic $\alpha$-syn.

\section{Discussion}

We have shown previously that passive immunization with the monoclonal antibody 9E4 ameliorates deficits in the PDGF- $\alpha$ syn tg model by promoting autophagy (Masliah et al., 2011). In the present immunotherapy study, we tested the efficacy of novel monoclonal antibodies against the CT truncation site of $\alpha$-syn $(1 \mathrm{H} 7,5 \mathrm{C} 1$, and 5D12) in an alternative PD-like model (mThy1$\alpha$-syn, line 61). We found that, comparable to 9E4, immunotherapy with the $1 \mathrm{H} 7$ and $5 \mathrm{C} 1$, and to a lesser extent 5D12, reduced the accumulation and propagation of CT-truncated $\alpha$-syn and improved the axonal and motor deficits via a mechanism that might involve protecting $\alpha$-syn from CT cleavage.

Immunotherapy with the $5 \mathrm{C} 1$ analog of $9 \mathrm{E} 4$, but not with the 5D12 analog, reduced $\alpha$-syn accumulation and related deficits in vivo. Consistent with this finding, 5D12 blocked the CT cleavage of $\alpha$-syn and the propagation of $\alpha$-syn to a lesser extent. The explanation for these differences in activity between $5 \mathrm{C} 1$ and $5 \mathrm{D} 12$ is not clear. In the in vivo studies 5D12 titers were lower than $5 \mathrm{C} 1$ and $1 \mathrm{H} 7$, but comparable to 9E4. However, and consistent with previous studies, 9E4 was efficacious at titers comparable to 5D12 (Masliah et al., 2011). Moreover, in the in vitro assays, all of the antibodies were used at the same concentrations. This suggests that there is probably a conformational difference in the detection sensitivity of 9E4, 5C1, and $1 \mathrm{H} 7$ compared with 
5D12. In support of this possibility, when 5D12 was compared with the other antibodies by immunoblot, the active antibodies such as 9E4 and 5C1 recognized the $12 \mathrm{kDa}$ CT-truncated fragment of $\alpha$-syn, whereas 5D12 only detected the FL- $\alpha$-syn at 14 $\mathrm{kDa}$. Moreover, by immunocytochemistry 9E4, $1 \mathrm{H} 7$, and $5 \mathrm{C} 1$ detected $\alpha$-syn accumulation in the neuronal cell bodies and neuropil, whereas 5D12 labeled mostly the neuronal perikaryon.

In addition to the novel effects of 5C1 (an analog of 9E4), the present study also showed significant activity of the $1 \mathrm{H} 7$ monoclonal antibody in the in vivo and in vitro assays, which was prepared against a slightly upstream site of the CT of $\alpha$-syn (aa 91-99). Interestingly, $1 \mathrm{H} 7$ recognized the $12 \mathrm{kDa}$ CT-truncated fragment of $\alpha$-syn by immunoblot. The mechanisms through which $5 \mathrm{C} 1$ and $1 \mathrm{H} 7$ might block the CT truncation of $\alpha$-syn are not clear. However, it is known that the misfolded $\alpha$-syn penetrates the cell membrane (Reynolds et al., 2011; Winner et al., 2011; Tsigelny et al., 2012), where it can be recognized by antibodies. In the case of $1 \mathrm{H} 7$, the aa 91-99 region of $\alpha$-syn is close to the highly hydrophobic and amyloidogenic NAC domain (61-95; Uéda et al., 1993; Iwai et al., 1995a; Iwai, 2000), and binding to domains in proximity with NAC could modify the folding of $\alpha$-syn and potentially block the CT truncation. Additional NMR and biophysical structural studies will be needed to better understand how the antibodies interact with $\alpha$-syn and modify its folding.

It has been suggested that the truncated species of $\alpha$-syn can originate from its incomplete degradation by the proteasome (Liu et al., 2005) and lysosomes via cathepsin D degradation (Sevlever et al., 2008). Several proteases, such as neurosin (Kasai et al., 2008), metalloproteinases (Sung et al., 2005; Levin et al., 2009), and calpain-1 (Mishizen-Eberz et al., 2003), have also been reported to cleave $\alpha$-syn in vitro. Calpain-1 cleaves $\alpha$-syn predominantly in the CT region after aa 114 and 122 (Mishizen-Eberz et al., 2003), and aggregates containing this CT-truncated $\alpha$-syn have been recovered from the brains of PD/DLB patients and in $\alpha$-syn tg models (Dufty et al., 2007; Nuber et al., 2013). In the brains of PD/DLB patients, as well as in tg mice, CT-cleaved $\alpha$-syn accumulates in abnormal axons and synapses and correlates with neuronal dysfunction (Games et al., 2013). Previous studies have demonstrated that calpain-1-mediated truncation renders $\alpha$-syn prone to aggregate (Mishizen-Eberz et al., 2005). Further, its presence in the core of Lewy bodies (Dufty et al., 2007; Muntané et al., 2012) and its conversion into neurotoxic oligomers that can propagate form cell to cell (Luk et al., 2012) indicates a role of CT-cleaved $\alpha$-syn as a possible seed in PD $\alpha$-syn aggregate formation. Utilizing a new antibody that recognizes the free calpain-1 CT of $\alpha$-syn (SYN105), we have shown recently that this accumulation is a prominent event in our mThyl- $\alpha$-syn tg mice (Games et al., 2013). Moreover, mThy1- $\alpha$-syn tg mice displayed significant motor deficits (Fleming et al., 2004) and neurodegenerative phenotype that includes axonopathy (Games et al., 2013) and loss of TH-positive fibers in the striatum (Chesselet et al., 2012), making them an excellent model for testing the efficiency of passive immunotherapy against the CT of $\alpha$-syn.

Our results suggest that CT antibodies might stabilize the CT domain of $\alpha$-syn, making it less prone to proteolytic (and maybe also nonproteolytic) truncation. Reducing CT truncation might have as a consequence a reduction in toxic aggregate formation and seeding-mediated propagation. However, based on our studies, we cannot rule out the possibility that the beneficial effects of antibodies might involve other mechanisms as well. Furthermore, enzymes that cleave the CT of $\alpha$-syn, such as calpain-1, are usually membrane bound (Sato et al., 1995), so one hypothetical site of interaction between $\alpha$-syn, antibodies, and CT-cleaving enzymes would be the plasma membrane. Previous studies suggest that $\alpha$-syn penetrates the membrane, thus facilitating the incorporation of additional $\alpha$-syn monomers in the complex and the formation of oligomers in the membrane (Tsigelny et al., 2012). However, recent studies have shown that antibodies might primarily target extracellular $\alpha$-syn (Bae et al., 2012), so the proteolytic protector effects in vivo would have to be against secreted enzymes such as matrix metalloproteinases (Sung et al., 2005). Our results show that, under certain conditions such as $\alpha$-syn overexpression, calpain-1 can be released to the extracellular environment. It has been observed that 1-methyl-4-phenylpyridiniumtreated dopaminergic cells can release soluble factors such as calpain that activate microglia and are selectively toxic to other neurons (Levesque et al., 2010). Calpains are also externalized during certain inflammatory processes and play a role in the microenvironment of inflammatory cells (Ménard and el-Amine, 1996). The presence of extracellular calpain suggests that CT- $\alpha$ syn could not only be generated intracellularly, but also in the extracellular space under pathological conditions. In this scenario, it is conceivable that antibodies targeting specific epitopes on $\alpha$-syn would block both the CT truncation and propagation of extracellular $\alpha$-syn, thus reducing its accumulation and neurotoxicity. This hypothesis is schematized in Figure 12.

Recent studies have shown that $\alpha$-syn oligomers can be released by affected neurons and propagate to adjacent neurons and glial cells, leading to neurotoxicity and inflammatory responses (Desplats et al., 2009; Brundin et al., 2010; Lee et al., 2010; Angot et al., 2012; Bae et al., 2012; Danzer et al., 2012; Lee et al., 2012), suggesting that immunotherapy might work by recognizing extracellular $\alpha$-syn (Valera and Masliah, 2013). In support of this possibility, we found that the antibodies against CTtruncated $\alpha$-syn that were most effective in vivo were those that blocked the propagation of $\alpha$-syn from neuron to neuron in vitro. The rationale for these experiments was based on recent studies showing that $\alpha$-syn proteolysis enhances toxicity (Li et al., 2005; Mishizen-Eberz et al., 2005; Michell et al., 2007) and propagation, and can occur in the extracellular space (Choi et al., 2011).

Finally, it is unclear what triggers $\alpha$-syn aggregation in sporadic forms of PD/DLB (Lashuel et al., 2013). Alterations in $\alpha$-syn synthesis, aggregation, or clearance have been proposed to affect the formation of toxic oligomers (Cuervo et al., 2004; Crews et al., 2009; Crews et al., 2010). Therefore, strategies directed at reducing the CT truncation of $\alpha$-syn, reducing $\alpha$-syn propagation, and/or promoting the clearance of oligomers might be of therapeutic value for PD/DLB. We have shown previously that immunization with antibodies against the CT of $\alpha$-syn can ameliorate the behavioral and neuropathological deficits in tg mice by enhancing lysosomal clearance of $\alpha$-syn (Masliah et al., 2005; Masliah et al., 2011; Valera and Masliah, 2013) and, in the present study, we have found that immunization also reduces CT cleavage and propagation of $\alpha$-syn. Together, these studies support the value of immunotherapy with antibodies directed against the CT of $\alpha$-syn for PD.

\section{References}

Angot E, Steiner JA, Lema Tomé CM, Ekström P, Mattsson B, Björklund A, Brundin P (2012) Alpha-synuclein cell-to-cell transfer and seeding in grafted dopaminergic neurons in vivo. PLoS One 7:e39465. CrossRef Medline

Bae EJ, Lee HJ, Rockenstein E, Ho DH, Park EB, Yang NY, Desplats P, Masliah E, Lee SJ (2012) Antibody-aided clearance of extracellular $\alpha$-synuclein prevents cell-to-cell aggregate transmission. J Neurosci 32:13454-13469. CrossRef Medline

Bar-On P, Crews L, Koob AO, Mizuno H, Adame A, Spencer B, Masliah E 
(2008) Statins reduce neuronal alpha-synuclein aggregation in in vitro models of Parkinson's disease. J Neurochem 105:1656-1667. CrossRef Medline

Bellucci A, Navarria L, Zaltieri M, Missale C, Spano P (2012) alphaSynuclein synaptic pathology and its implications in the development of novel therapeutic approaches to cure Parkinson's disease. Brain Res 1432: 95-113. CrossRef Medline

Brundin P, Melki R, Kopito R (2010) Prion-like transmission of protein aggregates in neurodegenerative diseases. Nat Rev Mol Cell Biol 11:301307. CrossRef Medline

Chesselet MF, Richter F, Zhu C, Magen I, Watson MB, Subramaniam SR (2012) A progressive mouse model of Parkinson's disease: the Thyl-aSyn ("Line 61") mice. Neurotherapeutics 9:297-314. CrossRef Medline

Choi DH, Kim YJ, Kim YG, Joh TH, Beal MF, Kim YS (2011) Role of matrix metalloproteinase 3-mediated alpha-synuclein cleavage in dopaminergic cell death. J Biol Chem 286:14168-14177. CrossRef Medline

Conway KA, Harper JD, Lansbury PT (1998) Accelerated in vitro fibril formation by a mutant alpha-synuclein linked to early-onset Parkinson disease. Nat Med 4:1318-1320. CrossRef Medline

Crews L, Tsigelny I, Hashimoto M, Masliah E (2009) Role of synucleins in Alzheimer's disease. Neurotox Res 16:306-317. CrossRef Medline

Crews L, Spencer B, Desplats P, Patrick C, Paulino A, Rockenstein E, Hansen L, Adame A, Galasko D, Masliah E (2010) Selective molecular alterations in the autophagy pathway in patients with Lewy body disease and in models of alpha-synucleinopathy. PLoS One 5:e9313. CrossRef Medline

Cuervo AM, Stefanis L, Fredenburg R, Lansbury PT, Sulzer D (2004) Impaired degradation of mutant alpha-synuclein by chaperone-mediated autophagy. Science 305:1292-1295. CrossRef Medline

Danzer KM, Kranich LR, Ruf WP, Cagsal-Getkin O, Winslow AR, Zhu L, Vanderburg CR, McLean PJ (2012) Exosomal cell-to-cell transmission of alpha synuclein oligomers. Mol Neurodegener 7:42. CrossRef Medline

Desplats P, Lee HJ, Bae EJ, Patrick C, Rockenstein E, Crews L, Spencer B, Masliah E, Lee SJ (2009) Inclusion formation and neuronal cell death through neuron-to-neuron transmission of alpha-synuclein. Proc Natl Acad Sci U S A 106:13010-13015. CrossRef Medline

Dickson DW (2001) Alpha-synuclein and the Lewy body disorders. Curr Opin Neurol 14:423-432. CrossRef Medline

Dufty BM, Warner LR, Hou ST, Jiang SX, Gomez-Isla T, Leenhouts KM, Oxford JT, Feany MB, Masliah E, Rohn TT (2007) Calpain-cleavage of alpha-synuclein: connecting proteolytic processing to disease-linked aggregation. Am J Pathol 170:1725-1738. CrossRef Medline

Fleming SM, Salcedo J, Fernagut PO, Rockenstein E, Masliah E, Levine MS, Chesselet MF (2004) Early and progressive sensorimotor anomalies in mice overexpressing wild-type human alpha-synuclein. J Neurosci 24: 9434-9440. CrossRef Medline

Galvin JE, Lee VM, Trojanowski JQ (2001) Synucleinopathies: clinical and pathological implications. Arch Neurol 58:186-190. CrossRef Medline

Games D, Seubert P, Rockenstein E, Patrick C, Trejo M, Ubhi K, Ettle B, Ghassemiam M, Barbour R, Schenk D, Nuber S, Masliah E (2013) Axonopathy in an alpha-synuclein transgenic model of Lewy body disease is associated with extensive accumulation of C-terminal-truncated alphasynuclein. Am J Pathol 182:940-953. CrossRef Medline

George JM, Jin H, Woods WS, Clayton DF (1995) Characterization of a novel protein regulated during the critical period for song learning in the zebra finch. Neuron 15:361-372. CrossRef Medline

Halliday G (2007) Clinicopathological aspects of motor parkinsonism. Parkinsonism Relat Disord 13:S208-S210. CrossRef Medline

Hashimoto M, Masliah E (1999) Alpha-synuclein in Lewy body disease and Alzheimer's disease. Brain Pathol 9:707-720. CrossRef Medline

Iwai A (2000) Properties of NACP/alpha-synuclein and its role in Alzheimer's disease. Biochim Biophys Acta 1502:95-109. CrossRef Medline

Iwai A, Yoshimoto M, Masliah E, Saitoh T (1995a) Non-A beta component of Alzheimer's disease amyloid (NAC) is amyloidogenic. Biochemistry 34:10139-10145. CrossRef Medline

Iwai A, Masliah E, Yoshimoto M, Ge N, Flanagan L, de Silva HA, Kittel A, Saitoh T (1995b) The precursor protein of non-A beta component of Alzheimer's disease amyloid is a presynaptic protein of the central nervous system. Neuron 14:467-475. CrossRef Medline

Iwatsubo T, Yamaguchi H, Fujimuro M, Yokosawa H, Ihara Y, Trojanowski JQ, Lee VM (1996) Purification and characterization of Lewy bodies from the brains of patients with diffuse Lewy body disease. Am J Pathol 148:1517-1529. Medline
Kasai T, Tokuda T, Yamaguchi N, Watanabe Y, Kametani F, Nakagawa M, Mizuno T (2008) Cleavage of normal and pathological forms of alphasynuclein by neurosin in vitro. Neurosci Lett 436:52-56. CrossRef Medline

Kramer ML, Schulz-Schaeffer WJ (2007) Presynaptic alpha-synuclein aggregates, not Lewy bodies, cause neurodegeneration in dementia with Lewy bodies. J Neurosci 27:1405-1410. CrossRef Medline

Lansbury PT Jr (1999) Evolution of amyloid: what normal protein folding may tell us about fibrillogenesis and disease. Proc Natl Acad Sci U S A 96:3342-3344. CrossRef Medline

Lashuel HA, Overk CR, Oueslati A, Masliah E (2013) The many faces of $\alpha$-synuclein: from structure and toxicity to therapeutic target. Nat Rev Neurosci 14:38-48. CrossRef Medline

Lee HJ, Suk JE, Patrick C, Bae EJ, Cho JH, Rho S, Hwang D, Masliah E, Lee SJ (2010) Direct transfer of alpha-synuclein from neuron to astroglia causes inflammatory responses in synucleinopathies. J Biol Chem 285:92629272. CrossRef Medline

Lee SJ, Desplats P, Lee HJ, Spencer B, Masliah E (2012) Cell-to-cell transmission of $\alpha$-synuclein aggregates. Methods Mol Biol 849:347-359. CrossRef Medline

Levesque S, Wilson B, Gregoria V, Thorpe LB, Dallas S, Polikov VS, Hong JS, Block ML (2010) Reactive microgliosis: extracellular micro-calpain and microglia-mediated dopaminergic neurotoxicity. Brain 133:808-821. CrossRef Medline

Levin J, Giese A, Boetzel K, Israel L, Högen T, Nübling G, Kretzschmar H, Lorenzl S (2009) Increased alpha-synuclein aggregation following limited cleavage by certain matrix metalloproteinases. Exp Neurol 215:201208. CrossRef Medline

Li W, West N, Colla E, Pletnikova O, Troncoso JC, Marsh L, Dawson TM, Jäkälä P, Hartmann T, Price DL, Lee MK (2005) Aggregation promoting C-terminal truncation of alpha-synuclein is a normal cellular process and is enhanced by the familial Parkinson's disease-linked mutations. Proc Natl Acad Sci U S A 102:2162-2167. CrossRef Medline

Liu CW, Giasson BI, Lewis KA, Lee VM, Demartino GN, Thomas PJ (2005) A precipitating role for truncated alpha-synuclein and the proteasome in alpha-synuclein aggregation: implications for pathogenesis of Parkinson disease. J Biol Chem 280:22670-22678. CrossRef Medline

Luk KC, Kehm VM, Zhang B, O’Brien P, Trojanowski JQ, Lee VM (2012) Intracerebral inoculation of pathological alpha-synuclein initiates a rapidly progressive neurodegenerative alpha-synucleinopathy in mice. J Exp Med 209:975-986. CrossRef Medline

Masliah E, Rockenstein E, Veinbergs I, Mallory M, Hashimoto M, Takeda A, Sagara Y, Sisk A, Mucke L (2000) Dopaminergic loss and inclusion body formation in alpha-synuclein mice: implications for neurodegenerative disorders. Science 287:1265-1269. CrossRef Medline

Masliah E, Rockenstein E, Veinbergs I, Sagara Y, Mallory M, Hashimoto M, Mucke L (2001) beta-amyloid peptides enhance alpha-synuclein accumulation and neuronal deficits in a transgenic mouse model linking Alzheimer's disease and Parkinson's disease. Proc Natl Acad Sci U S A 98: 12245-12250. CrossRef Medline

Masliah E, Rockenstein E, Adame A, Alford M, Crews L, Hashimoto M, Seubert P, Lee M, Goldstein J, Chilcote T, Games D, Schenk D (2005) Effects of alpha-synuclein immunization in a mouse model of Parkinson's disease. Neuron 46:857-868. CrossRef Medline

Masliah E, Rockenstein E, Mante M, Crews L, Spencer B, Adame A, Patrick C, Trejo M, Ubhi K, Rohn TT, Mueller-Steiner S, Seubert P, Barbour R, McConlogue L, Buttini M, Games D, Schenk D (2011) Passive immunization reduces behavioral and neuropathological deficits in an alphasynuclein transgenic model of Lewy body disease. PLoS One 6:e19338. CrossRef Medline

McKeith IG (2000) Spectrum of Parkinson's disease, Parkinson's dementia, and Lewy body dementia. Neurol Clin 18:865-902. CrossRef Medline

Ménard HA, el-Amine M (1996) The calpain-calpastatin system in rheumatoid arthritis. Immunology Today 17:545-547. CrossRef Medline

Michell AW, Tofaris GK, Gossage H, Tyers P, Spillantini MG, Barker RA (2007) The effect of truncated human alpha-synuclein (1-120) on dopaminergic cells in a transgenic mouse model of Parkinson's disease. Cell Transplant 16:461-474. CrossRef Medline

Mishizen-Eberz AJ, Guttmann RP, Giasson BI, Day GA 3rd, Hodara R, Ischiropoulos H, Lee VM, Trojanowski JQ, Lynch DR (2003) Distinct cleavage patterns of normal and pathologic forms of alpha-synuclein by calpain I in vitro. J Neurochem 86:836-847. CrossRef Medline 
Mishizen-Eberz AJ, Norris EH, Giasson BI, Hodara R, Ischiropoulos H, Lee VM, Trojanowski JQ, Lynch DR (2005) Cleavage of alpha-synuclein by calpain: potential role in degradation of fibrillized and nitrated species of alpha-synuclein. Biochemistry 44:7818-7829. CrossRef Medline

Muntané G, Ferrer I, Martinez-Vicente M (2012) alpha-synuclein phosphorylation and truncation are normal events in the adult human brain. Neuroscience 200:106-119. CrossRef Medline

Murphy DD, Rueter SM, Trojanowski JQ, Lee VM (2000) Synucleins are developmentally expressed, and alpha-synuclein regulates the size of the presynaptic vesicular pool in primary hippocampal neurons. J Neurosci 20:3214-3220. Medline

Murray IV, Giasson BI, Quinn SM, Koppaka V, Axelsen PH, Ischiropoulos H, Trojanowski JQ, Lee VM (2003) Role of alpha-synuclein carboxyterminus on fibril formation in vitro. Biochemistry 42:8530-8540. CrossRef Medline

Nuber S, Harmuth F, Kohl Z, Adame A, Trejo M, Schönig K, Zimmermann F, Bauer C, Casadei N, Giel C, Calaminus C, Pichler BJ, Jensen PH, Müller $\mathrm{CP}$, Amato D, Kornhuber J, Teismann P, Yamakado H, Takahashi R, Winkler J, Masliah E, Riess O (2013) A progressive dopaminergic phenotype associated with neurotoxic conversion of alpha-synuclein in BACtransgenic rats. Brain 136:412-432. CrossRef Medline

Oueslati A, Fournier M, Lashuel HA (2010) Role of post-translational modifications in modulating the structure, function and toxicity of alphasynuclein: implications for Parkinson's disease pathogenesis and therapies. Prog Brain Res 183:115-145. CrossRef Medline

Price DL, Rockenstein E, Ubhi K, Phung V, MacLean-Lewis N, Askay D, Cartier A, Spencer B, Patrick C, Desplats P, Ellisman MH, Masliah E (2010) Alterations in mGluR5 expression and signaling in Lewy body disease and in transgenic models of alpha-synucleinopathy-implications for excitotoxicity. PLoS One 5:e14020. CrossRef Medline

Reynolds NP, Soragni A, Rabe M, Verdes D, Liverani E, Handschin S, Riek R, Seeger S (2011) Mechanism of membrane interaction and disruption by alpha-synuclein. J Am Chem Soc 133:19366-19375. CrossRef Medline

Rockenstein E, Mallory M, Hashimoto M, Song D, Shults CW, Lang I, Masliah E (2002) Differential neuropathological alterations in transgenic mice expressing alpha-synuclein from the platelet-derived growth factor and Thy-1 promoters. J Neurosci Res 68:568-578. CrossRef Medline

Rockenstein E, Crews L, Masliah E (2007) Transgenic animal models of neurodegenerative diseases and their application to treatment development. Adv Drug Deliv Rev 59:1093-1102. CrossRef Medline

Roy S, Winton MJ, Black MM, Trojanowski JQ, Lee VM (2007) Rapid and intermittent cotransport of slow component-b proteins. J Neurosci 27: 3131-3138. CrossRef Medline

Sato K, Saito Y, Kawashima S (1995) Identification and characterization of membrane-bound calpains in clathrin-coated vesicles from bovine brain. Eur J Biochem 230:25-31. CrossRef Medline

Savica R, Grossardt BR, Bower JH, Ahlskog JE, Rocca WA (2013) Incidence and pathology of synucleinopathies and tauopathies related to Parkinsonism. JAMA Neurol 70:859-866. CrossRef Medline

Sevlever D, Jiang P, Yen SH (2008) Cathepsin D is the main lysosomal enzyme involved in the degradation of alpha-synuclein and generation of its carboxy-terminally truncated species. Biochemistry 47:9678-9687. CrossRef Medline
Spencer B, Potkar R, Trejo M, Rockenstein E, Patrick C, Gindi R, Adame A, Wyss-Coray T, Masliah E (2009) Beclin 1 gene transfer activates autophagy and ameliorates the neurodegenerative pathology in alphasynuclein models of Parkinson's and Lewy body diseases. J Neurosci 29: 13578-13588. CrossRef Medline

Stefanis L (2012) $\alpha$-Synuclein in Parkinson's disease. Cold Spring Harb Perspect Med 2:a009399. CrossRef Medline

Sung JY, Park SM, Lee CH, Um JW, Lee HJ, Kim J, Oh YJ, Lee ST, Paik SR, Chung KC (2005) Proteolytic cleavage of extracellular secreted \{alpha\}synuclein via matrix metalloproteinases. J Biol Chem 280:25216-25224. CrossRef Medline

Taschenberger G, Garrido M, Tereshchenko Y, Bähr M, Zweckstetter M, Kügler S (2012) Aggregation of alphaSynuclein promotes progressive in vivo neurotoxicity in adult rat dopaminergic neurons. Acta Neuropathol 123:671-683. CrossRef Medline

Tiscornia G, Singer O, Verma IM (2006) Production and purification of lentiviral vectors. Nat Protoc 1:241-245. CrossRef Medline

Trojanowski JQ, Lee VM (1998) Aggregation of neurofilament and alphasynuclein proteins in Lewy bodies: implications for the pathogenesis of Parkinson disease and Lewy body dementia. Arch Neurol 55:151-152. CrossRef Medline

Tsigelny IF, Sharikov Y, Miller MA, Masliah E (2008) Mechanism of alphasynuclein oligomerization and membrane interaction: theoretical approach to unstructured proteins studies. Nanomedicine 4:350-357. CrossRef Medline

Tsigelny IF, Sharikov Y, Wrasidlo W, Gonzalez T, Desplats PA, Crews L, Spencer B, Masliah E (2012) Role of $\alpha$-synuclein penetration into the membrane in the mechanisms of oligomer pore formation. FEBS J 279: 1000-1013. CrossRef Medline

Ubhi K, Rockenstein E, Mante M, Inglis C, Adame A, Patrick C, Whitney K, Masliah E (2010) Neurodegeneration in a transgenic mouse model of multiple system atrophy is associated with altered expression of oligodendroglial-derived neurotrophic factors. J Neurosci 30:62366246. CrossRef Medline

Uéda K, Fukushima H, Masliah E, Xia Y, Iwai A, Yoshimoto M, Otero DA, Kondo J, Ihara Y, Saitoh T (1993) Molecular cloning of cDNA encoding an unrecognized component of amyloid in Alzheimer disease. Proc Natl Acad Sci U S A 90:11282-11286. CrossRef Medline

Valera E, Masliah E (2013) Immunotherapy for neurodegenerative diseases: focus on $\alpha$-synucleinopathies. Pharmacol Ther 138:311-322. CrossRef Medline

Volpicelli-Daley LA, Luk KC, Patel TP, Tanik SA, Riddle DM, Stieber A, Meaney DF, Trojanowski JQ, Lee VM (2011) Exogenous alphasynuclein fibrils induce Lewy body pathology leading to synaptic dysfunction and neuron death. Neuron 72:57-71. CrossRef Medline

Weinreb PH, Zhen W, Poon AW, Conway KA, Lansbury PT Jr (1996) NACP, a protein implicated in Alzheimer's disease and learning, is natively unfolded. Biochemistry 35:13709-13715. CrossRef Medline

Winner B, Jappelli R, Maji SK, Desplats PA, Boyer L, Aigner S, Hetzer C, Loher T, Vilar M, Campioni S, Tzitzilonis C, Soragni A, Jessberger S, Mira H, Consiglio A, Pham E, Masliah E, Gage FH, Riek R (2011) In vivo demonstration that alpha-synuclein oligomers are toxic. Proc Natl Acad Sci U S A 108:4194-4199. CrossRef Medline 